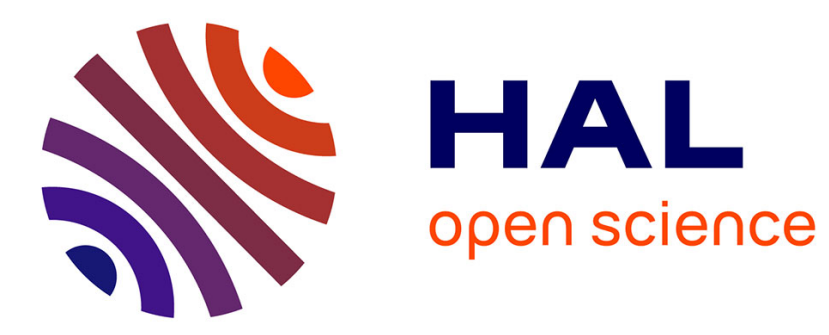

\title{
Knowledge, Capabilities and Manufacturing Innovation: A US-Europe Comparison
}

Stephen Roper, Jan Youtie, Philip Shapira, Andrea Fernandez Ribas

\section{To cite this version:}

Stephen Roper, Jan Youtie, Philip Shapira, Andrea Fernandez Ribas. Knowledge, Capabilities and Manufacturing Innovation: A US-Europe Comparison. Regional Studies, 2010, 44 (03), pp.253-279. 10.1080/00343400802360410 . hal-00579787

\section{HAL Id: hal-00579787 https://hal.science/hal-00579787}

Submitted on 25 Mar 2011

HAL is a multi-disciplinary open access archive for the deposit and dissemination of scientific research documents, whether they are published or not. The documents may come from teaching and research institutions in France or abroad, or from public or private research centers.
L'archive ouverte pluridisciplinaire HAL, est destinée au dépôt et à la diffusion de documents scientifiques de niveau recherche, publiés ou non, émanant des établissements d'enseignement et de recherche français ou étrangers, des laboratoires publics ou privés. 


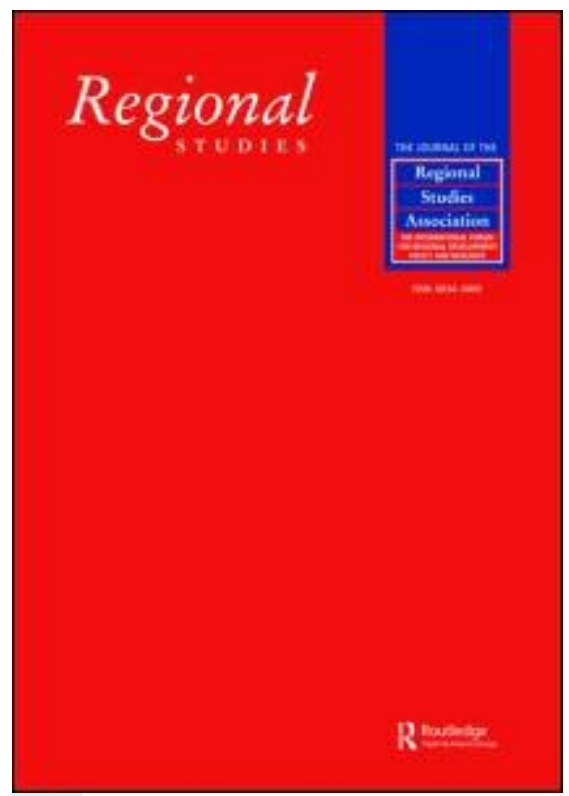

\section{Knowledge, Capabilities and Manufacturing Innovation: A US-Europe Comparison}

\begin{tabular}{|r|l|}
\hline Journal: & Regional Studies \\
\hline Manuscript ID: & CRES-2007-0071.R2 \\
\hline Manuscript Type: & Main Section \\
\hline JEL codes: & $\begin{array}{l}\text { L60 - General < L6 - Industry Studies: Manufacturing }<\text { L - } \\
\text { Industrial Organization, O14 - Industrialization; Manufacturing; } \\
\text { Service Industries; Tech Choice < O1 - Economic Development < O } \\
\text { - Economic Development, Technological Change, and Growth, O18 - } \\
\text { O O - Economic Development, Technological Change, and Growth, } \\
\text { Technological Change|Research and Development }<\text { O O - Economic } \\
\text { Development, Technological Change, and Growth }\end{array}$ \\
\hline Keywords: & $\begin{array}{l}\text { Knowledge capabilities, Manufacturing, Innovation, Innovation } \\
\text { Policy }\end{array}$ \\
\hline
\end{tabular}

\section{s) ScholarONE" \\ Manuscript Central}




\title{
Knowledge, Capabilities and Manufacturing
}

\section{Innovation: A US-Europe Comparison}

\author{
STEPHEN ROPER ${ }^{1}$, JAN YOUTIE ${ }^{2}$, \\ PHILIP SHAPIRA $^{3}$ and ANDREA FERNANDEZ RIBAS ${ }^{4}$
}

${ }^{1}$ Centre for Small and Medium Sized Enterprises, Warwick Business School, University of Warwick, Coventry, CV4 7AL, UK.

Email: stephen.roper@wbs.ac.uk

\author{
${ }^{2}$ Enterprise Innovation Institute, Georgia Institute of Technology, \\ Atlanta, GA 30332-0640, USA; Email: jan.youtie@innovate.gatech.edu \\ ${ }^{3}$ Manchester Institute of Innovation Research, Manchester Business School, \\ University of Manchester, M13 9PL, UK; and School of Public Policy, Georgia \\ Institute of Technology, Atlanta, GA 30332-0345 USA. \\ Email:pshapira@mbs.ac.uk
}

${ }^{4}$ School of Public Policy, Georgia Institute of Technology Atlanta, GA 30332-0345, USA; Email: afribas@gatech.edu

\section{First received: March 2007}

Accepted: April 2008 


\begin{abstract}
This paper presents a comparative analysis of factors contributing to the innovation performance of manufacturing firms in Georgia (USA), Wales (UK), the West Midlands (UK), and Catalonia (Spain). Enabled by comparable survey data, multivariate probit models are developed to estimate how various types of firms' innovative activities are influenced by links to external knowledge sources, internal resources, absorptive capacity and public innovation support. Our results suggest the potential for mutual learning. For the European study regions there are insights about how universities in Georgia support innovation. For Georgia and Catalonia there are lessons from UK firms about better capturing potential complementarities between innovation activities. Additional implications for innovation measurement and knowledge base development are discussed.
\end{abstract}

Knowledge capabilities; Manufacturing; Innovation; Regional innovation policy

JEL classifications: L60, O14, O18, O32, R11

Les capacités intellectuelles et l'innovation industrielle: Une comparaison des E-U avec l'Europe.

$\underline{\text { Roper et al. }}$

$\underline{\text { Cet article cherche à présenter une analyse comparative des facteurs qui contribuent à }}$ la performance de l'innovation des entreprises industrielles en Géorgie (aux E-U), aux Pays de Galles (au R-U), dans les West Midlands (au R-U), et en Catalogne (en Espagne). A partir des enquêtes qui fournissent des données comparables, on construit des modèles du type probit à plusieurs variables afin d'estimer comment les activités innovatrices des diverses types d'entreprises se voient influencer par des liens avec des sources de connaissance externes, des ressources internes, la capacité d'absorption et le soutien publique en faveur de l'innovation. Les résultats laissent supposer un potentiel d'apprentissage commun. Pour les régions européennes qui figurent dans 
l'étude, il y a des aperçus sur la façon dont les universités situées en Géorgie soutiennent l'innovation. Pour la Géorgie et la Catalogne, il y a des leccons à tirer des entreprises situées au R-U quant à la saisie efficace des complémentarités potentielles des activités innovatrices. On discute des retombées supplémentaires concernant la $\underline{\text { mesure de l'innovation et le développement d'une base de connaissance. }}$

Capacités intellectuelles / Industrie / Innovation / Politique régionale en faveur de l'innovation

Classement JEL: L60; O14; O18; O32; R11

\section{Wissen, Kapazitäten und Produktionsinnovation: ein Vergleich zwischen den USA und Europa STEPHEN ROPER, JAN YOUTIE, PHILIP SHAPIRA and ANDREA FERNANDEZ RIBAS}

In diesem Beitrag stellen wir eine vergleichende Analyse der Faktoren vor, die zur Innovationsleistung produzierender Firmen in Georgia (USA), Wales (GB), den West Midlands (GB) und Katalonien (Spanien) beitragen. Mit Hilfe von vergleichbaren Erhebungsdaten entwickeln wir multivariate Probit-Modelle, um abzuschätzen, wie die innovativen Aktivitäten verschiedener Arten von Firmen durch die Verknüpfungen zu externen Wissensquellen, internen Ressourcen, absorptiver Kapazität und öffentlicher Innovationsunterstützung beeinflusst werden. Unsere Ergebnisse weisen darauf hin, dass die Regionen voneinander lernen können. Für die europäischen Regionen der Studie gibt es Einblicke, wie die Universitäten in Georgia die Innovation unterstützen. In Georgia und Katalonien kann vom Beispiel der britischen Firmen gelernt werden, wie sich potenzielle Komplementaritäten innerhalb der Innovationsaktivitäten besser nutzen lassen. Es werden zusätzliche Implikationen zur Messung von Innovation und zur Entwicklung einer Wissensbasis erörtert.

Wissenskapazität

Produktion

Innovation

Regionale Innovationspolitik

JEL classifications: L60, O14, O18, O32, R11

Conocimiento, capacidades e innovación manufacturera: comparación entre EE.UU. y Europa Stephen Roper, Jan Youtie, Philip Shapira And Andrea Fernandez Ribas

En este artículo presentamos un análisis comparativo de los factores que contribuyen al rendimiento de innovación de empresas manufactureras en Georgia (EE.UU.), Gales (RU), West Midlands (RU), y Cataluña (España). Con ayuda de datos de estudios comparables, desarrollamos modelos probit de multivarianza para calcular de qué modo los diferentes tipos de 
actividades innovadoras de las empresas están influenciadas por los vínculos con fuentes externas de conocimiento, fuentes internas, capacidad absorbente y soporte público de innovación. Nuestros resultados indican que existe la posibilidad de un aprendizaje mutuo. Para las regiones europeas del estudio se puede aprender de qué modo las universidades en Georgia fomentan la innovación. Georgia y Cataluña podrían aprender de las empresas británicas a captar mejor las posibles complementariedades entre las actividades de innovación. Analizamos también las implicaciones adicionales para la medición de la innovación y el desarrollo de bases de conocimiento.

Capacidades de conocimiento

Fabricación

Innovación

Política de innovación regional

JEL classifications: L60, O14, O18, O32, R11 


\section{Knowledge, Capabilities and Manufacturing Innovation: A US-Europe Comparison}

\section{INTRODUCTION}

Over recent years the internationalisation of product markets has contributed to intensified international competition, particularly from producers in low-cost countries. For firms in high labour-cost areas such as the US and Europe these pressures have reshaped firms' strategic options, de-emphasising cost-based competition and emphasising product design, performance and customer service (QUAH, 2001). Meeting the challenge of this increasing competition requires innovation in products, processes and the ways in which businesses organise and market their products. Moreover, recent work on innovation suggests that firms' ability to innovate depends not only on their own internal competencies but also on external knowledge sources and the quality of the innovation systems, networks and supply chains in which they are operating. In particular, the availability of external knowledge sources for innovation - such as universities, intermediate technology institutes, and standards setting bodies - have all been seen as significant enablers of

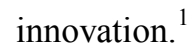

In this paper we focus on how firms in the US and Europe are able to innovate to meet the common challenges posed by intensified global competition. We explore firms' internal resources and capabilities, their absorptive capacity and the supportiveness of the innovation system within which they operate. More specifically, we compare the factors which contribute to the innovation performance of manufacturing firms in Georgia in the US South, the UK regions of Wales and the West Midlands, and the Spanish region of Catalonia. Each of these areas is broadly similar in terms of business R\&D spending, and each is a region in which the 
manufacturing sector, concentrated in traditional industries, is undergoing considerable restructuring as a response to increasing international competition. In Georgia, traditional sectors such as food processing, textiles, and pulp and paper continue to dominate the manufacturing base combined with a high level of external ownership (YOUTIE and SHAPIRA, 2007). In the UK West Midlands, a strong tradition of metal-based industries, including the automotive sector, is giving way to a more diverse, if smaller, manufacturing sector with limited new inward investment (LOVE et al., 2006). In Wales, inward investment has been more significant, attracted by an intensive regional support regime, and has contributed to a shift in the industrial sector from a traditional concentration in metals manufacturing and processing and other heavy industries towards electronics and white goods production (COOKE et al., 1995; COOKE, 2004; FULLER et al., 2004). In Catalonia, the regional economy has experienced profound change over the last two decades following Spain's entry to the European Union (EU). The region's industrial structure is highly diversified and open. Textiles, metalworking and food processing continue to be major employment sources, but chemicals, transport equipment and machinery are also important in terms of total industrial gross added value (BACARIA et al., 2004).

For firms in these regions, facing intense international competition, broadlybased innovation is necessary to upgrade product offerings and simultaneously improve business efficiency and customer service (SHERGILL and NARGUNDKAR, 2005; BAKER and GILL, 2005). The research literature stresses the interdependence of these different aspects of innovation, particularly those linked to human resource management (HRM) and organisational innovation (DAWSON et al., 2005), advanced manufacturing techniques (AMT) and product innovation (MICHIE and SHEEHAN, 2003). Hence, in our empirical analysis we aim to capture the diversity of innovation 
behaviours by considering product and process innovation alongside the adoption of advanced manufacturing techniques, marketing approaches and organisational structures. We model explicitly the potential complementarities between these different types of innovation. ZENGER (2002), for example, suggests that we might expect to see different patterns of complementarities between different types of innovation leading to 'discrete organizational choices'. We also probe the role of aspects of the innovation system external to the firm. Three empirical questions are therefore addressed in the paper. First, what factors are shaping firms' innovation activities in each study region? Second, what pattern of innovation complementarities do we observe? And, third, how effectively are the relevant state and regional innovation systems supporting firms' innovation activities?

Our empirical analysis is based on innovation survey data covering manufacturing firms in each of the study regions - specifically, the Georgia Manufacturing Survey, the UK Innovation Survey, and the Spanish Innovation Survey. Much progress has been made in recent years in the design and conduct of such innovation surveys, drawing on international standards established by the Organisation for Economic Cooperation and Development and the EU Community Innovation Survey. Nonetheless, some issues of international comparability inevitably remain. This point should be kept mind in the interpretation of our results, particularly where these depend on international comparisons.

The next section develops our conceptual framework and reviews other recent studies which focus on the determinants of firm-level innovation. This is followed by a discussion of our study regions, focussing on the structure of the manufacturing sector and the institutional supports for firm-level innovation. We then describe our 
data sources and empirical methodology. The final sections present our main empirical results and conclusions.

\section{CONCEPTUAL APPROACH}

The starting point for our analysis is the now standard innovation production function which reflects the process of knowledge transformation, in which knowledge sourced by the enterprise is translated into innovation outputs of various types (GEROSKI, 1990; HARRIS and TRAINOR, 1995; LOVE and ROPER, 2001). The effectiveness of firms' knowledge transformation activity is then influenced by the strength of the firm and its ability to absorb external knowledge (LOVE and ROPER, 1999; ROPER et al., 2006). In general terms, therefore, we can write the innovation production function for an individual innovation output as:

$I_{i}=\phi_{0}^{\prime} K S_{k i}+\phi_{1} R I_{i}+\phi_{2} A C A P_{i}+\phi_{3} G O V T_{i}+\varepsilon_{i}$

Where $\mathrm{I}_{\mathrm{i}}$ is an innovation output indicator, $\mathrm{KS}_{\mathrm{ki}}$ are the sources of knowledge which provide the basis for firms' innovation activity, $\mathrm{RI}_{\mathrm{i}}$ is a set of indicators representing the scale and scope of firms' internal resources, $A C A P_{i}$ is a set of indicators intended to reflect firms' absorptive capacity - the ability to take in and apply new knowledge (COHEN and Levinthal, 1989, 1990; ZAHRA and GeORge, 2002), GOVT $T_{i}$ reflects firms' access to public support for innovation and upgrading, and $\varepsilon_{\mathrm{i}}$ is the error term. Sign expectations here are generally positive. In terms of the knowledge sources, for example, we expect positive and significant signs where a knowledge source is an important driver of firms' innovation activity. Similarly, where firms' internal resources are strong, we would expect this to contribute positively to the efficiency 
with which firms are able to transform knowledge inputs into new innovations (LöÖF and Heshmati, 2001, 2002). We also expect firms' innovation outputs to be positively related to their absorptive capacity and the receipt of government support for innovation or upgrading (see ROPER and HEWITT-DUNDAS, 2005).

A major limitation with the innovation production function in its standard form is its focus on a single innovation output measure. Both empirical and conceptual arguments suggest that this approach is limited and potentially misleading. In empirical terms, for example, BROUWER and KLEINKNECHT (1996) demonstrate that different innovation output measures may give a significantly different impression of firms' relative 'innovativeness' and the determinants of innovation. They therefore argue that in terms of empirical inference alone it is more appropriate to focus on a 'basket' of measures rather than a single innovation indicator (see also PITTAWAY et al., 2004). However, this remains an unsettled issue. For example, FrEEL (2005) suggests that the determinants of product and process innovation are analogous, while other recent research (FALK, 2006; SCHMIDT and RAMMER, 2006) finds similarities in factors contributing to technological and organisational innovation. Nonetheless, conceptual arguments for adopting a holistic multi-indicator approach to firms' innovation activity remain persuasive, with a focus on the potential for tradeoffs (HAYES et al., 1988) or complementarities between types of innovative activity (MILGROM and ROBERTS, 1990, 1995).

In terms of the innovation production function, this suggests the potential for simultaneity between different forms of innovative activity, i.e. that ceteris paribus a firm engaging in one type of innovative activity is either more, or less, likely to also be engaging in other types of innovation. In behavioural terms, it is useful to envisage firms' strategic decision to invest resources in each innovation activity as the outcome 
of a comparison of the costs and anticipated benefits. LEVIEN and REISS (1984), for example, derive first order conditions which relate the extent of firms' innovation activity to anticipated price-cost margins. However, varied effects may result from the mix of innovation activities adopted by firms. A tradeoffs perspective suggests the pursuit of multiple innovation objectives at the same time risks mediocrity, and that firms should therefore adapt more focussed priorities (HAYES et al., 1988). Similarly, PORTER (1980) distinguishes competition based on cost versus differentiation, advocating that companies either pursue one or the other competitive strategy (with follow-on implications for innovation activity selection) in order to achieve a leadership position.

A contrasting perspective emphasises complementarity, in other words, that undertaking one form of innovation has either a positive effect on the anticipated returns from another innovation activity, a negative effect on the costs of undertaking that activity, or both (see SAMUELSON, 1974, on complementarity in economics). In terms of anticipated returns, for example, the sales resulting from product innovation may benefit positively from concurrent marketing innovation. ATHEY and SCHMUTZLER (1995) examine the circumstances in which the implementation of product innovation increases the likelihood that process and organizational innovation will also be introduced. Their (theoretical) model suggests that flexibility in product design and processes should, in most cases, result in subsequent innovations in products and processes. Conversely, in terms of the costs of innovation, process change might, for example, be more economically undertaken where it is accompanied by either managerial or organisational changes. Based on a study of the Spanish ceramic tile industry, MiraVete and Permias (2004) develop a model to discriminate between innovation complementarities and associations that stem from 
unobserved factors. Their results suggest that product and process innovation are significantly complementary. For example, the single firing furnace (a technologically-oriented process innovation) gave rise to new product designs and organizational approaches to making these new products.

As the conceptual arguments are balanced, we regard the question of whether there are tradeoffs or complementary relationships between innovation activities as a matter for further empirical investigation. Our presumption, however, given the evidence of other studies is towards the likelihood of complementarities between types of innovative activity (e.g. FALK, 2006). In either case, modelling the possibility of trade-off/complementarity effects requires a generalisation of equation (1) to allow for simultaneity between innovation indicators

$$
I_{j i}=\phi_{j 0}{ }^{\prime} K S_{k i}+\phi_{11} R I_{i}+\phi_{j 2} A C A P_{i}+\phi_{j 3} G O V T_{i}+\phi_{j 4} I_{k i}+\varepsilon_{j i}
$$

Where $\mathrm{j}$ denotes a particular type of innovation activity and $\mathrm{j} \neq \mathrm{k}$. In equation (2), $\phi_{\mathrm{j} 4}$ will be positive for complementarities or negative for trade-off effects. Note also that we anticipate potential error covariance such that $\mathrm{E}\left(\varepsilon_{\mathrm{ji}} \varepsilon_{\mathrm{ki}}\right)=\sigma_{\mathrm{jk}}$. As our innovation output indicators are simple indicator variables suggesting whether firms are engaged in each particular type of innovation, the appropriate estimator is multivariate probit.

\section{STUDY REGIONS}

Our empirical study design examines our expectations and questions about firms’ knowledge sourcing and innovation strategies in four regions: one in the US and three in Europe. This multi-regional approach allows us to probe relationships between internal knowledge and innovation strategies and external connectivity and, in 
particular, to analyze the influence of differential regional support systems on innovation strategies and outcomes. The choice of the US study region was shaped by the availability of unique innovation survey data for Georgia manufacturing firms (YOUTIE et al., 2005). The European study regions were then chosen to reflect some of the broad structural characteristics of Georgia's manufacturing sector. In the selected European regions, as in Georgia, traditional industries are still important despite recent restructuring, a significant number of externally-controlled (branch) plants are present, there are numerous smaller industrial firms, and there are generally low levels of R\&D spending compared to other highly industrialized regions. Basic structural statistics for each study region are presented in Table 1, which also provides some indicators of the economic climate in the study regions at the time of the comparison. For example, unemployment rates in the UK and US regions were relatively similar, although there was more labour market inactivity in Catalonia. Per capita incomes were also marginally higher in the US and UK West Midlands region than in Catalonia and Wales. However, R\&D intensity was quite similar across the regions. An overview of each region follows.

\section{Georgia}

Georgia is the ninth largest US state and one of the fastest growing with a current population of just over 9 million (Table 1). The development of the state has made it emblematic of the American Sunbelt region's rapid expansion. However, much of the recent growth has occurred in services, with continuing falls over the last few years in overall manufacturing employment. In 2005, manufacturing accounted for around 13 per cent of Georgia's gross state product, a lower proportion than that in any of the European study regions but comparable to the level for the US as a whole. 
(Manufacturing value added comprised 12.1 percent of 2005 US gross domestic product, see BUREAU OF ECONOMIC ANALYSIS, 2007.) In terms of the number of establishments, Georgia's manufacturing sector is diverse. However, employment is concentrated in the state's traditional resource-based sectors such as food processing, textiles, and pulp and paper. These three industries accounted for 42 percent of manufacturing jobs in the state in 2003 and more than half of rural Georgia's industrial base. In addition, the US South is known as a region of branch plants and in Georgia more than 40 percent of manufacturing units are branch plants.

Private sector research and development (R\&D) is lower in Georgia than in much of the US, although levels of university R\&D are closer to the US average (Table 1). Although Georgia ranked ninth in population in 2003, it ranked $22^{\text {nd }}$ in the level of industrial R\&D (NATIONAL SCIENCE Foundation, 2006) The industrial make-up of Georgia's industry contributes to the state's relatively low ranking in terms of private R\&D. Nationally, company expenditures for $R \& D$ as a percentage of net sales were $0.47,0.82$, and 1.06 respectively for Georgia's three traditional industries of food processing, textiles and wood products, compared with 3.63 for all US industries (NATIONAL ScIENCE Foundation, 2005, Table A-2). Over the last two decades, Georgia has developed a series of policies, programs and public-private partnerships to expand research-based high technology industries in the state, with some success in recent years in increasing high tech start-ups particularly in Atlanta, the state's largest metropolitan region. Georgia has also developed (with federal and state funds) an extensive manufacturing extension system, organized by the state's leading technological university (Georgia Institute of Technology), to provide industrial support and knowledge transfer services to existing manufacturing establishments (SHAPIRA, 2005). 


\section{Wales}

Wales is the smallest of the four study regions in terms of population $(2.95 \mathrm{~m})$, has the lowest workforce employment rate, and a relatively low per capita income (Table 1). It is one of the 'devolved' territories of the UK with considerable discretion over most aspects of social and economic policy (although see MORGAN, 2002). This has led to regional policies focussed on promoting inward investment in high-tech sectors, strengthening the skills base and encouraging innovation and enterprise (COOKE et al., 1995; COOKE, 2004). The effectiveness of this policy strategy has been questioned (see, for example, FULLER and PHELPS, 2004) but it is clear that inward investment has been a major factor in reshaping the Welsh manufacturing sector over recent years. BRAND et al. (2000), for example, suggest that in 1995, 39 per cent of the output of manufacturing industry in the sectors they considered was generated by externally-owned firms which accounted for 29 per cent of total employment. Manufacturing inward investment to the region has been concentrated in two main sectors (electronic and electrical engineering and automotive components) although there have also been large-scale investments in other transport sectors (e.g. aeronautical engineering).

In 2003, manufacturing accounted for more than 18 per cent of GDP in Wales, considerably more than that in Georgia but around the same level as the West Midlands (Table 1). Levels of R\&D spending in Wales are similar to those in Georgia and Catalonia but generally lower than the UK average both in terms of business and higher education R\&D spending.

\section{The West Midlands}


Often described as the manufacturing heartland of the UK, the West Midlands has a population of just over five million, larger than that of Wales but smaller than Georgia and Catalonia (Table 1). Levels of economic activity in the region are high, as measured by the workforce employment rate, and this contributes to an average per capita income that is greater than for Wales. Traditionally, the West Midlands manufacturing sector had a strong focus on metal-based industries, with a significant automotive sector. Recent high profile plant closures (including the 2005 collapse of the MG-Rover Group) have reduced this emphasis somewhat but manufacturing remains concentrated in traditional medium-tech, engineering sectors. Manufacturing inward investment to the region has been less important than in Wales and strongly concentrated in the automotive sector and related industries (BRAND et al., 2000). Reflecting the composition of industry in the West Midlands, levels of R\&D spending in the region are similar to those in Wales, Catalonia and Georgia, and below the UK average (Table 1). Recent commentaries on this have tended to emphasise the difficulty this suggests for firms' absorptive capacity - a factor which, in the West Midlands, is exacerbated by relatively low workforce skill levels (LovE $e t$ al., 2006).

\section{Catalonia}

Catalonia remains the most industrialized among the study regions (Table 1), despite as in the other regions, the relative importance of manufacturing has fallen in recent years as services have grown. Catalonia's manufacturing base is still significant in regional and national contexts. In 2003, manufacturing industries employed 23.2 percent of total regional employment and accounted for 23.4 percent of regional gross value added, representing more than 25 per cent of Spain's industrial gross value 
added. Many types of manufacturers operate in Catalonia, although the region is most specialized in medium-high and medium-low-technology industries.

Catalonia is known for its strong entrepreneurial tradition and the importance of small and medium enterprises, often family owned. Of the region's industrial firms, more than half of employ fewer than five workers and just less than one per cent employ more than 200 workers. Numerous types of industrial networks of collaborating firms have been identified in the region, including public, private and semi-public organizations (BACARIA, et al., 2004). Firms' high level of industrial association, and the diverse nature of networking organisations, seem to be signalling the existence of high levels of social capital in the region. The systemic nature of industrial relations has been studied under the "regional innovation systems" framework, leading to the conclusion that this concept is applicable for Catalonia (BACARIA, et al, 2004).

The openness of the system has been increasing since Spain's 1986 accession to the European Union and the creation of the European Single Market in 1993. Since then Catalan firms have become more internationalised, currently, exporting more to the European markets than to the national market. Foreign direct investment into the region is also significant, and now plays an important part in the technology acquisition model. However, when knowledge indicators are considered, the picture is quite different. In a recent study FERNANDEZ-RIBAS AND SHAPIRA (2007) find that Catalan firms rarely cooperate with foreign partners as part of their innovation activity. Catalan firms seem to be facing considerable challenges to access European competitive public R\&D funding and to set up partnerships with foreign partners.

While Catalonia remains a major manufacturing region, like the other three study regions it has pursued a medium-level technological path. At $1.2 \%$ of gross 
regional product, the overall level of $\mathrm{R} \& \mathrm{D}$ expenditure in the region is lower than the European average, but similar to Georgia, Wales and West Midlands (Table 1).

Traditionally, the region's exporting capacity has been based on competing through low labour costs and prices coupled with high productivity in mature industrial sectors such as chemicals and transport equipment (FERNANDEZ-RIBAS, 2003). However, this model is under increasing competitive pressure from new EU members and other nonEU countries that have cheap yet skilled human capital. Catalan's current human capital level does not seem sufficient to facilitate the transition to new innovation models based on competition via high-value added products. In fact, the region has a growing relative disadvantage in specialized human capital and scientific personnel. However, it is also worth noting that the informal nature of innovation and R\&D in Catalan SMEs is not well captured by official R\&D statistics. In this regard, the broader measures of knowledge sourcing and innovation analyzed in our study should give a fuller picture of the strategies of regional manufacturers, as the following section discusses.

\section{DATA AND METHODS}

The common element in the multi-regional data used in our study is that all our sources are based on innovation surveys. In contrast to conventional indicators of R\&D spending or patenting, innovation surveys seek to track a broader range of innovation capabilities and performance including the development and application of new product, process, organizational, and marketing innovations at the enterprise level. A primary reference point for innovation surveys is the 'Oslo Manual' - a set of guidelines established by the Organization for Economic Cooperation and

Development (OECD) for collecting data on technological innovation (see OECD, 
2005). More than 50 countries have undertaken innovation surveys (MOHAPATRA et al. 2006) using these guidelines, including member states of the European Union through the Community Innovation Survey (CIS). The CIS has a two-fold purpose: (1) to monitor the level of innovation within private sector firms and (2) to provide a statistical basis for innovation policy. The first CIS was conducted in Europe in the 1992-93 timeframe; this survey is currently in its fourth iteration and the fifth CIS is planned for 2008 (see, for example, EUROPEAN COMMUNITIES, 2004)

For the US, there is no equivalent to the European CIS. National surveys conducted by the Census Bureau or the National Science Foundation incorporate elements related to innovation (such as R\&D expenditures), but they do not as yet seek to measure the full range of innovation-related activities. To the best of our knowledge, the only innovation survey that has been conducted with consistency in the US - and which uses questions comparable to those of the CIS - is the Georgia Manufacturing Survey. This has been conducted in Georgia in 1994, 1996, 1999, 2002 and 2005 (with a 2008 round planned). For our study, data is taken from the 2005 Georgia Manufacturing Survey. This is a postal survey of manufacturing establishments in the state with 10 or more employees, with responses being weighted to reflect the industry-employment size distribution of firms as reported in the Georgia Department of Labour's ES202 database (which is collected under a federalstate programme and comprehensively covers all employers hiring workers subject to state unemployment insurance provisions). The Georgia Manufacturing Survey is addressed either to a senior manager by name or to the title "general manager," with survey responses completed by the $\mathrm{CEO}$, managing director, general manager, plant manager or other senior manager of the facility. Data presented in this paper is based 
on an analysis of 653 manufacturing establishments whose management responded to the 2005 Georgia Manufacturing Survey (see also YoutIE, et al., 2005).

Our study data for Wales and the West Midlands is drawn from the 2005 UK Innovation Survey, the latter being part of the fourth CIS wave. The 2005 UK Innovation Survey covers the majority of sectors of the UK economy, targeting the senior managers of enterprises with more than 10 employees (ROBSON and ORTMANS, 2006). The sampling frame for the survey was developed from the official interdepartmental business register, with the survey being conducted by post. The overall response rate was 58 per cent ( 16,446 responses) although no sectoral breakdown of this is available. Weights were developed to give regionally representative results. The analysis reported here is based on the 413 responses by Welsh manufacturing firms, and the 559 responses by West Midlands manufacturers. Data for Catalan firms comes from the third wave of the Spanish Innovation Survey. The Spanish Innovation Survey covers manufacturing and service firms with more than 10 employees for the period 1998-2000. Firms that do not report new or significantly improved innovation products or processes do not have to answer the whole questionnaire, including questions about innovation expenditures, R\&D, effects of innovation, public support to $R \& D, R \& D$ cooperation, and sources of information for innovation. Our analysis for Catalan firms is therefore restricted to those that reported product or process innovation, a group of 930 manufacturing firms in all. The more specific nature of the Catalan data somewhat limits the direct compatibility with the US and UK study regions, essentially narrowing the range of indicator strategies encompassed by the analysis. For example, Catalonian firms engaging solely in organisational innovation without either product or process change are excluded from the analysis. This limitation to the Catalan data is likely to affect the 
assessment of complementarities since the range of innovation strategies included in the Catalan data is somewhat reduced. Nonetheless, the Catalan case serves to illustrate how the value chain model behaves for a sub-sample of product and process innovators.

In all comparative survey-based studies, such as that reported here, data comparability is a major issue. Previous work has used matched data across multiple CIS and other innovation surveys (ROPER and HEwITT-DunDAS, 2006). The three surveys used in our analysis are consistent with OECD and CIS guidelines which provide a common set of definitions of product and process innovation. ${ }^{2}$ Recent additions have seen the incorporation of organizational innovations - including strategy, management, structures and marketing - to the standard definition of innovation. ${ }^{3}$ Descriptive data for innovation activities and a range of explanatory factors for these firms is presented in Table 2. For each region, we model firms' participation in five different types of innovation activity representing the adoption of AMT, organisational innovation, marketing innovation, product innovation and process innovation using simple binary dummies.

Overall proportions of firms undertaking each type of innovation are very similar in the two UK study regions with product and process change the most common and AMT adoption least common. Percentages are higher for the Catalan region as they refer to product and process innovators. For Georgia, the proportions of innovating firms are notably higher for each type of innovation. This is consistent with other US-UK comparisons which have suggested that US firms are in general marginally more innovation-active than UK firms (e.g. CAMBRIDGE-MIT, 2006). Reassuringly, however, despite these levels differences, the ordering of innovation types among manufacturing firms in Georgia is identical to that in the UK study 
regions and broadly similar to that in Catalonia (Table 2). Note also the generally strong and positive correlation coefficients between our different innovation indicators suggesting complementarities between the different innovation activities (Table 3). Notably the one exception to this general pattern is the negative correlation between product and process innovation in Catalonia.

A key driver of innovation is knowledge sourced outside the firm, and here we distinguish between six routes through which firms are able to source the knowledge needed for innovation (ROPER, et al., 2006). First, in-house research and development $(R \& D)$ may create new knowledge but may also help to increase firms' absorptive capacity. $R \& D$ is defined as "creative work undertaken within the enterprise to increase the stock of knowledge and its use to devise new and improved goods, services and processes." ${ }^{, 4}$ Second, knowledge transfer from other group members - from other companies or units within the firm's enterprise group - may enable a firm to benefit from R\&D undertaken elsewhere in a multi-plant or multinational company. Third, forwards links, defined as knowledge sourced from customers or clients, may assist firms in innovation through a better appreciation of customer requirements or market trends. Fourth, backwards links, defined as knowledge sourced from suppliers of equipment, materials, services, or software, may enable firms to identify new technologies or potential process changes. Fifth, horizontal links, defined as knowledge sourced from competitors or joint ventures, may suggest new market opportunities. Finally, firms' links to public knowledge sources, such as universities, public sector laboratories, or technology programmes, as part of their innovation activities may provide access to leading edge technologies or technical assistance. 
Profiles of knowledge sourcing in Wales and the West Midlands are, like those for innovation, relatively similar with West Midlands firms less likely to engage in R\&D but more likely to engage in external knowledge sourcing than those in Wales (Table 2). Firms in Georgia exhibit a more extreme pattern with R\&D less common than in either of the two UK study regions but stronger patterns of connectivity to other firms. Catalonia shows yet another pattern of results in terms of knowledge sharing. Backward, forward and horizontal linkages are uniformly less common than in the UK regions and Georgia. Interestingly, the percentage of firms with cooperative agreements with public knowledge sources is higher in Catalonia than in the UK regions, in part due to the growing tendency to subcontract basic and applied research to universities and also the regional government's promotion of an $\mathrm{R} \& \mathrm{D}$ subcontracting market (FERNANDEZ-RIBAS, 2003). However, significant effects from such agreements are, as yet, not picked up in the innovation survey data.

These results seem to suggest that Catalonia is not as advanced in terms of connections for innovation, despite being a region with abundant industry networks for purposes of procurement and supply. Our statistical analysis finds that Catalan firms do not seem to take full advantage of the innovation potential of business interrelationships. Rather they show a traditional cooperation pattern limited to information sharing and low value added activities. A priori, we would expect the higher level of connectivity among firms in Georgia to be contributing positively to higher innovation rates. In terms of firms' resources it is clear that firms in Georgia are on average smaller (in 2002 at the start of the period) and older than those in the two UK study regions (Table 2). On the basis of previous studies, we would expect both factors to be reducing levels of innovation in Georgia relative to the UK. Other resource and absorptive capacity indicators are broadly similar for firms in Georgia 
and the UK regions and Catalonia. Overall, therefore, our descriptive analysis suggests that higher levels of innovation among firms in Georgia may be linked to higher levels of connectivity and knowledge sharing.

In addition to the direct drivers of innovation we are also interested in potential complementarities between types of innovation activity, in other words the significance of $\varphi_{\mathrm{j} 4}$ in equation 2. In practice, however, we experienced substantial difficulty in obtaining convergence with the full degree of simultaneity implied by equation 2 in a multivariate probit. Instead, therefore we develop a more general indication of complementarities based on a series of alternative variables $\mathrm{C}_{\mathrm{ki}} \mathrm{k}=1,5$ where $C_{k i}=1$ if $I_{j i}=1$ for any $j \neq k$, and 0 otherwise. In other words, $C_{k i}$ takes value 1 where a firm is engaged in any of the other forms of innovation, and 0 if the firm is not engaging in any of the other forms of innovation. (See Table 2 for descriptives.) Coefficients on $\mathrm{C}_{\mathrm{ki}}$ therefore provide a more generalised view of complementarities or trade-offs between different types of innovation than the $\phi_{\mathrm{j} 4}$ of equation 2. Our final estimating equation is therefore the five-equation multivariate probit model $(\mathrm{j}=1,5)$ :

$I_{j i}=\phi_{j 0}{ }^{\prime} K S_{k i}+\phi_{11} R I_{i}+\phi_{j 2} A C A P_{i}+\phi_{j 3} G O V T_{i}+\phi_{j 5} C_{k i}+\varepsilon_{j i}$

Where, as before, we anticipate potential error covariance such that $\mathrm{E}\left(\varepsilon_{\mathrm{ji}} \varepsilon_{\mathrm{ki}}\right)=\sigma_{\mathrm{jk}}$.

\section{EMPIRICAL RESULTS}

Tables 4, 56 and 7 give multivariate probit estimates for Georgia, Wales, the West Midlands, and Catalonia respectively, and Table 8 summarises the results symbolically. In general terms the multivariate probit models perform relatively well, significantly outperforming random assignment and identifying a range of significant 
factors. Significant error covariances also suggests the value of the simultaneous estimation approach rather than single equation probit models. ${ }^{5}$

The first aspect of interest in the models is the potential complementarity between types of innovation, and it is here that we see the strongest contrasts between the four regions. In the UK regions of Wales and the West Midlands, reflecting the pattern of previous European studies (FALK, 2006; SCHMIDT and RAMMER, 2006) we find positive and significant complementarities between all five types of innovation suggesting perhaps economies of scope in the management of innovation or more functional or operational complementarity. In Georgia, we find a more neutral pattern with no evidence of such complementarities. Several explanations are possible. For firms in Georgia, it may be that functional separation in management is more strongly maintained than for the UK firms in the study. In this case, where managers focus solely on their own functional area with little input into other areas, this might reduce the potential for cross-functional learning by management from innovation in other aspects of firms' activities. Alternatively, it could be that the strategic intent underlying innovation in firms in Georgia is more focussed than that in the UK. For example, if innovation in firms in Georgia was more focussed on process development than in the UK study regions (Table 2) this might have less synergy with other forms of innovation than product change which seems predominant in the UK. Catalan firms also demonstrate few innovation complementarities, but the strength of this result should be put in the context of product and process innovators. ${ }^{6}$ The Catalan case adds a new layer to our model in that it seems to be indicating that for a near-to-market innovation model the private value of complementarities is more limited. Positive externalities between product and process innovation do not emerge, 
suggesting that product and process innovation are reaching different types of firms and different types of innovation projects. Estimation results indeed suggest that product innovation and process innovation are largely driven by different factors. Product innovation is more likely among firms that do research activities and firms that invest capital on innovation. Process innovation is more likely among non-R\&D performers and firms from low-tech sectors. Firms that have some kind of knowledge absorptive capacity and train their employees also have significantly more chances to do process innovation. Asymmetries between both types of innovation are also manifested in the negative and highly significant correlation coefficients (Table 2). ${ }^{7}$ One possible interpretation of these points is that innovating firms in Catalonia do not appear to be managing highly technologically-complex projects that require complex organizational structures; rather they seem to have a traditional innovation strategy focused on technology adaptation and development of incremental technological innovations that are highly applied and near-to-market.

Other determinants of innovation suggest a more uniform picture across the four study regions. In terms of knowledge sourcing, for example, in-house R\&D is consistently important, although its effects are notably stronger in Georgia than in either of the European study regions. This is consistent with other studies of the determinants of firms' innovation activities, which consistently envisage $R \& D$ as a key direct driver of innovation (LöÖF and HeSHMATI, 2001, 2002) and as an important determinant of absorptive capacity (CASSIMAN and VeUgelers, 2002). As noted earlier, this latter point may be particularly significant in Georgia, where links between firms, and between firms and elements of the public knowledge base, seem better developed than those in the European study regions (Table 2). 
In terms of firms' external links, and their impact on innovation we also find some similarities between the four study regions. Backwards linkages - to suppliers for example, have positive and significant benefits for product change in each of the study regions, (except for the Catalan region) but are less strongly linked to organisational and market innovation or the adoption of AMTs. Forward linkages to clients or customers have less consistent benefits across the study regions but have positive impacts on product change (West Midlands and Georgia), AMT (Catalonia), organisational structure (West Midlands, Catalonia and Georgia) and marketing (Georgia). Interestingly, forward linkages do not appear so important for Welsh firms, although horizontal links appear most important for firms in Wales. This is of particular interest given the strength of policy initiatives in Wales to try and develop innovation networks and support collaborative working between firms (MORGAN et al., 2000). Equally important, however, is the general weakness of the contribution to innovation of firms' links to public knowledge sources, most notably the universities. In both the UK study regions these links are consistently insignificant, with the only significant, and positive, effect being on process innovation in Georgia. This result is consistent with the profile of support offered by the university-sponsored industrial services to firms in Georgia, which tend to focus on process change and optimisation (for instance, by promoting lean manufacturing). However, it is disappointing given the policy emphasis on developing more advanced university-company knowledge transfer activities in recent years on both sides of the Atlantic (LAMBERT, 2003; O'SHEA et al., 2005).

For firms' resource base, we find evidence that scale factors - related here to firm size at the start of the period - are most significant in terms of process innovation and innovation in organisational structures (Table 8). More generally, we find the 
standard inverted ' $U$ ' shape relationship between the probability of innovating and firm size noted elsewhere in the innovation literature (see KIM et al., 2004). Plant vintage is generally unimportant, but perhaps more interesting is the lack of very positive evidence of any consistent benefit to innovation from either group membership (or intra-group knowledge transfers). This is important given an argument in the academic literature on multi-national enterprises which suggests that intra-firm knowledge transfers are by-and-large effective and that, as a result, plants within multi-national groups tend to be more innovative and productive than similar independent operations (HEWITT-DUNDAS et al., 2005).

Absorptive capacity effects prove more consistently important particularly related to firms' investments in innovation related training and capital (Table 8). This serves to emphasise the importance of high quality human capital for innovation (see also FREEL, 2005) and the importance of related capital investments particularly as part of process change. What is less clear from our econometric evidence is the mechanism by which these effects are operating, in other words whether they represent an absorptive capacity effect, or whether they are activities directly corelated - or part of - particular innovation projects ${ }^{8}$. For example, it may be that undertaking training for innovation and capital investment enable, or make it easier, for firms to evaluate and implement innovation ideas gleaned from other firms or other external knowledge sources. In this situation, training and investment are enhancing firms' general absorptive capacity but may have no direct role in terms of specific innovation projects. In fact, our econometric evidence suggests that both effects may be operating, i.e. that project specific investments in training and capital equipment may also be having wider absorptive capacity effects. In particular, we see positive and significant training and investment effects in projects relating to process 
innovation, but weaker - perhaps absorptive capacity effects - on other forms of innovation activity.

Finally, our evidence on public support for innovation (including through grants, loans, loan guarantees and subsidies) is limited to the European study regions. In general terms, this public support for innovation has a positive effect, increasing the probability that firms will engage in each type of innovation. ${ }^{9}$ Perhaps the most interesting aspect of our results, however, is the apparent weakness of local or regional support measures for innovation, and the greater significance of national and supranational (European) support measures for innovation. The implication is that locally-oriented or organised measures - presumably focussed on either stimulating local innovation or connectivity - are actually less effective at stimulating innovation than measures designed to promote broader national (for example, the UK's Collaborative Research and Development programme) or international collaboration for innovation (for instance, through various initiatives of the European Union's Framework programmes). A potential explanation is that at a regional level it may be difficult to find appropriate - or high quality - partners for innovation, although these may be available nationally or internationally. This is consistent with the arguments made in COE and BLUNDELL (2003), which while recognising the importance of proximity to innovation also argue that trans-national innovation linkages can play an important role in knowledge creation (see also OINAS, 1999). In the context of Wales and the West Midlands, the empirical results of OERLEMANS et al (2003), are also relevant here. Based on Dutch data they suggest that localised innovation linkages are more important where innovation is highly complex. As indicated earlier, however, both the West Midlands Wales and Catalonia are generally low R\&D intensity regions with a concentration of manufacturing activity in medium-to-low R\&D-intensity 
industry. In this context, the results of OERLEMANS et al. (2003) suggest that local innovation networks might be less important than in regions with a stronger concentration of R\&D-intensive manufacturing.

\section{CONCLUSIONS}

In this paper we have addressed three main empirical questions, the first of which related to the dynamics and determinants of innovation in manufacturing firms in Georgia, Wales, the West Midlands and Catalonia. The second question probed the potential complementarities between different types of innovation. The third question examined the effectiveness of broader innovation systems in supporting manufacturing innovation in each of the study regions. In each case the reliability of our results depends on the international comparability of the innovation survey data we use for our analysis and we would stress the exploratory nature of our analysis. Each of the three surveys we use is, however, based on a standard set of definitions of innovation derived from OECD and EU guidelines and have identical target populations. Nonetheless, some caution is still relevant in interpreting the results due to potential differences in the way firms in each country respond to such surveys and differences in firms' operating environments.

In the analysis of our first question, overall, we find that Georgian firms have a slightly higher probability of undertaking innovation than their UK counterparts in terms of product, process, marketing, business organisation and the adoption of AMTs. Interestingly, however, the relative proportions of firms undertaking each type of innovation in the US and UK study regions are very similar. Results for the Catalan region complement these findings for a sample of product and process innovators. Our innovation production functions suggest two main factors which seem to be 
contributing to these higher levels of innovation in US firms. First, in the models we see significant and positive effects from firms' knowledge sourcing activities (Table 7), with the descriptive analysis suggesting that US firms have a generally higher level of external connectivity than that in UK and Catalan firms (Table 2). One possibility therefore is that the higher degree of 'association' (COOKE and MORGAN, 1999) between firms in Georgia may be contributing to higher levels of innovative activity in the region. Second, in Georgia we also see the only significant positive contribution from public knowledge sources to innovation (Tables 4 and 7) and this again is likely to be contributing to higher innovation propensity in the US, at least in terms of process change. Other factors, such as firms in-house R\&D and training and investment as part of firms' innovation activities prove important in each of the four study regions (Table 8). In evaluating these results it is important to acknowledge the context for our US- European comparison, i.e. the comparison is between regions in which manufacturing industry is restructuring and retains a strong presence in more traditional sectors. Earlier caveats regarding the international comparability of innovation survey data are also relevant here.

The second question focussed on potential complementarities between different types of innovation. Our prior was based on the likelihood of managerial learning to generate economies of scope between different forms of innovation activity, or the potential for functional synergy between different innovation activities. In our empirical results, we see markedly different patterns between the study regions: in both UK study regions we observe strong positive complementarities between different types of innovation activity; in Georgia we see no evidence of any such complementarities (Table 8). Potential explanations relate either to stronger functional separation in management in US firms - and therefore a failure to capture or transfer 
knowledge from one aspect of innovation to another - or to a more focussed approach to innovation in US firms than that adopted in the UK. In either case, our evidence suggests that US firms may not be taking full advantage of potential synergies between their innovation activities, something which is being achieved by firms in Wales and the West Midlands. A closer look at the sub-sample of product and process innovators gives an additional twist to our findings. Results for Catalan innovator firms indicate that complementarities between product and process may not be fully exploited when firms pursue very applied innovation strategies. Again, however, we would stress the exploratory nature of these observations.

Our results do allow is to depict the study regions in terms of their profiles of internal innovation synergies and external connectivity (Figure 1). None of our study regions score 'high' on each dimension, the type of position suggested for leading high technology regions by the open innovation model (CHESBOROUGH, 2003). Rather, our regions assume other positions on this matrix of possibilities. The UK regions of Wales and the West Midlands exhibit high internal innovation synergies with low external connectivity. Diagonally opposite is Georgia, with low internal innovation synergies and high external connectivity. On these measures, Catalonia trails the study group, with low performance in both external connectivity and, as far as we can assess it given the nature of the Catalonian sample, low internal innovation synergy. Another way of interpreting these results is in terms of the notion of the innovation funnel which illustrates the process by which an initial set of ideas are evaluated, tested and finally result in innovation (HAYES et al., 1988). The shape of the innovation development funnel can then be used to provide an indication of the breadth of the set of initial ideas being considered by a firm and the degree of attrition during the innovation process. In Georgia, the suggestion of greater connectivity 
among firms suggests a broader set of knowledge inputs to the innovation process than in the UK study regions, however, the more focussed approach to innovation being adopted in Georgia also suggests greater attrition or the elimination of innovation ideas. In the UK study regions, the lower level of connectivity suggests a narrower range of initial knowledge inputs to the innovation process; while the less focussed approach to firms' final innovation outputs suggests less attrition, or a development funnel which narrows more slowly. Catalonia is yet another case. Neither the use of external knowledge sources nor the level of synergies across innovative activities appears to be high. The lower external connectivity, as seen in the UK regions, is not per se inhibitory in further development of complementarities, but in this case it seems to be connected.

These differences in innovation behavior between US and European firms, however tentative, are worthy of some further comment. Why is, for example, that firms with, presumably, similar profit maximizing objectives adopt such contrasting innovation strategies? At least two explanations are plausible. First, there may be differentiated access to technical and market information between US and European firms. These informational asymmetries may be leading to the development of different innovation strategies. Second, and to the point of this study, it may be that there are important national and regional innovation system differences which are impacting on the innovation practices of firms, the way they access knowledge, and the relevance of local institutions such as universities. The contrasts in innovation behavior observed here also raise a further question: Is it better for firms to adopt a focused innovation strategy or one which is more broadly-based? For example, it might be argued that a more focused innovation strategy might allow a firm to move an innovation more quickly and flexibly into a market, such as in the case of new 
product introduction. This might be particularly true for small and medium-sized firms where limited absorptive capacity might make project-based, rather than portfolio-based, innovation a more realistic possibility. On the other hand, a more broadly-based innovation strategy might have better long-term payoffs, allowing firms to benefit from translating learning from one type of innovation to another. More importantly this approach suggests that there is a broader strategy that impacts firm decisions and innovation choices. Innovations may be better planned and executed under a holistic approach that takes into account not just product development (for example) but also how this product will affect processes, organizational structures, and marketing. This added level of integration may justify the effectiveness of the holistic strategy in the long-term.

Our third empirical question related to the effectiveness of the relevant state and regional innovation systems in supporting manufacturing innovation in each of the study regions. Two observations are relevant here. First, it has been argued that a key element of such local or regional innovation systems is the degree of association or linkage between firms, and our innovation production function estimates support this view emphasising the importance of external connectivity for innovation (Table 8). Of our four study regions, however, we see from the descriptive analysis the strongest external connectivity among firms in Georgia (Table 2), suggestive of a greater degree of knowledge sharing or diffusion among US firms than that evident in the UK and Spain. This inter-firm connectivity clearly matters for innovation given the positive and significant coefficients on the forwards, backwards and horizontal knowledge sharing terms in the probit models. Second, in terms of the contribution of public knowledge sources including universities to regional innovation we see stronger effects in Georgia than in either of the two UK study regions or Catalonia, 
although, as noted, earlier this effect is specific to process change. Our interpretation is that the greater degree of association between firms and the more positive contribution from public knowledge sources to innovation suggests a more supportive innovation milieu in Georgia than in the other study regions. Again, however, it is important to take into account the fact that each of the study regions is a restructuring region with relatively low levels of high-tech manufacturing activity and R\&D spending.

More generally, our results suggest something of a contrast. Firms in Georgia seem from our results to benefit from a more supportive external environment for innovation than firms in Wales and the West Midlands characterised by more knowledge sharing but do not exploit to the full potential complementarities between their innovation activities. For the European study regions there are therefore potential lessons here in terms of the way in which the universities in Georgia - and potentially other public knowledge providers - are supporting innovation in manufacturing firms. It may also be useful to explore further the reasons for the differential levels of connectivity between US, Spanish and UK firms. For firms in Georgia and Catalonia the potential lessons are more strategic or organisational. Why is it that UK firms are able to capture complementarities between their innovation activities which are not being captured by firms in Georgia and in Catalonia? Answering this latter question is likely to require more detailed and comparative case-study evidence than that currently available and it may also be useful to broaden the range of regions covered in future analysis to examine the generality of the patterns identified here to other UK and European regions. It is also important to acknowledge that the comparison conducted here is essentially cross-sectional, and will inevitably reflect economic conditions at the time the surveys were undertaken. It would therefore be useful to re- 
consider the results obtained here in a more longitudinal context. This would help to confirm causality between the variables considered here and also better account for the impact of economic context and market change on outcomes.

Finally, our results also raise an important measurement issue for consideration at national policy levels. Innovation has traditionally been represented, particularly in the US, by indicators such as patents, venture capital, and R\&D. Based on measures such as these, which tend to have an exclusively technological orientation, the US as a whole emerges as a global leader, giving rise to concerns about an innovation between the US and Europe (MERIT, 2006). On such metrics, leading US technological regions (such as California's Silicon Valley or Massachusetts' Route 128) do well, while other US regions such as Georgia display middling or weak performance. Yet this study has shown that, using a broader array of metrics, innovation does take place within Georgia manufacturers in important areas such as knowledge sourcing that are not picked up by conventional high technology innovation indicators. Moreover, there is something distinctive about the regional system within which Georgia firms operate relative to similar firms in the West Midlands and Wales with respect to the complementarities between innovation types. This level of information is obtained through the benchmarking of items in innovation surveys, particularly the analysis of a variety of innovation activity and knowledge linkage measures. Innovation surveys have attracted increased interest in the US recently, as debate has grown about improving and broadening measures of science, technology and innovation performance (MARBURGER, 2005; LIGHTFOOT, 2006). As yet there is no comprehensive national innovation survey undertaken in the US which is comparable to the CIS in Europe: to date, our results are limited to only one US region where a comparable data set has been established. However, this study 
has shown that important differences and similarities can be uncovered through the use of innovation surveys. There are, of course, limitations of such surveys (see, for example, TETHER, 2001; SALAZAR and HOLBROOK, 2004), and any insights obtained should be corroborated by other research to ensure a validated evidence base for policy. Nonetheless, if a regionally-representative national innovation survey were to be implemented in the US that had compatibility with the approaches used by CIS and other non-European countries, this could greatly strengthen the knowledge base for innovation policymaking, both in the US and elsewhere.

\section{Acknowledgements}

We acknowledge the Georgia Manufacturing Extension Partnership, the US

Economic Development Administration, and the Center for Paper and Business

Industry Studies at Georgia Tech for their sponsorship of the Georgia Manufacturing Survey 2005. Stephen Roper is grateful to the Department of Trade and Industry, UK for permission to make use of the individual, anonymised returns from the UK 2005 Innovation Survey. Thanks are also due to the Generalitat de Catalunya/Fulbright for providing funding to support Andrea Fernández-Ribas under the grant FGENCAT2004/39702274 and to IDESCAT for providing the Catalan data. This paper was completed while Stephen Roper was a visiting researcher at the School of Public Policy and the Enterprise Innovation Institute, Georgia Institute of Technology, Fall 2006. Valuable comments were received from: participants in the Fourth BritishIrish-Israel meeting of the Regional Science Association International, Ramat Gan, Israel, May 2007; participants in the British-Irish Regional Science Association Conference, Bangor, August 2007; James H Love, Aston; and, two anonymous 
referees. Views and judgements expressed in this paper should be attributed to the authors and not necessarily to any sponsors. 
Table 1: Descriptive Data for the Study Regions

\begin{tabular}{|c|c|c|c|c|}
\hline & $\begin{array}{c}\text { Georgia } \\
\text { (US) }\end{array}$ & $\begin{array}{l}\text { Wales } \\
\text { (UK) }\end{array}$ & $\begin{array}{c}\text { West } \\
\text { Midlands } \\
\text { (UK) }\end{array}$ & $\begin{array}{c}\text { Catalonia } \\
\text { (Spain) }\end{array}$ \\
\hline \multicolumn{5}{|l|}{ A. Land Area and Population } \\
\hline Land area $\left(\mathrm{km}^{2} \mathrm{x} 1000\right)$ & 154.1 & 20.8 & 13.0 & 32.1 \\
\hline Population (x million, 2005) & 9.1 & 3.0 & 5.3 & 6.7 \\
\hline Population density (per km², 2005) & 58.9 & 142.1 & 410.2 & 209.0 \\
\hline \multicolumn{5}{|l|}{ B. Labour Market and Per Capita income } \\
\hline Working age employment rate $(\%, 2005)$ & 72.2 & 70.8 & 77.6 & 69.3 \\
\hline Unemployment rate $(\%, 2005)$ & 4.9 & 4.5 & 4.4 & 7.0 \\
\hline Per capita income (US\$ x 1000 pa, 2003/2004) & 30.0 & 24.3 & 28.0 & 26.5 \\
\hline \multicolumn{5}{|l|}{ C. Composition of GSP $(\%, 2003 / 2005)$} \\
\hline Primary (agriculture, fishing, mining) & 1.2 & 1.9 & 1.3 & 1.9 \\
\hline Manufacturing & 12.7 & 18.7 & 18.9 & 23.4 \\
\hline Utilities, transport, communications, construction & 10.8 & 15.1 & 15.8 & 17.6 \\
\hline Wholesale, retail, hotels, restaurants, other services & 19.2 & 19.4 & 20.8 & 23.3 \\
\hline Finance, real estate, business service & 32.5 & 21.2 & 25.9 & 21.3 \\
\hline Education, health, social and public services & 23.6 & 23.8 & 17.3 & 12.6 \\
\hline \multicolumn{5}{|l|}{ D. R\&D Spending (\% of GSP, 2002) } \\
\hline R\&D Spending & 1.2 & 1.2 & 1.0 & 1.2 \\
\hline - Industry & 0.6 & 0.7 & 0.7 & 0.8 \\
\hline - Higher education & 0.3 & 0.4 & 0.3 & 0.3 \\
\hline - Other & 0.2 & 0.1 & 0.0 & 0.1 \\
\hline
\end{tabular}

Notes: GSP = Gross State/Regional Product; Working age employment rate is defined as the level of employment as a proportion of the working age population. Unemployment rates are defined relative to the labour force. Per capita income is Gross Value Added (GVA) or GSP per capita, with UK figures converted to US Dollars using the 2004 average exchange rate $(£ 1=\$ 1.83)$. R\&D spending figures are expressed as a proportion of GSP. GVA or GSP composition relates to 2003 for UK regions and 2005 for Georgia.

Sources: Georgia: population and labour market data, Mapstats, available at:

http://www.fedstats.gov/qf/states/13000.html; regional GSP data from Table 3. GDP by State in

Current Dollars, 2005. Available at: http://bea.gov/bea/newsrel/gspnewsrelease.htm\#table1; Wales and

West Midlands, Regional Trends 38 and 39, National Statistics, http://www.statistics.gov.uk;

Catalonia: European Regional Statistics, available at http://epp.eurostat.ec.europa.eu, and IDESCAT

http://www.idescat.cat 
Table 2: Survey Descriptives

\begin{tabular}{|c|c|c|c|c|c|c|c|c|}
\hline & \multicolumn{2}{|c|}{ Georgia $(\mathrm{N}=653)$} & \multicolumn{2}{|c|}{ Wales $(\mathrm{N}=413)$} & \multicolumn{2}{|c|}{ West Midlands $(\mathrm{N}=538)$} & \multicolumn{2}{|c|}{ Catalonia $(\mathrm{N}=930)$} \\
\hline & Mean & SD & Mean & Std. Dev. & Mean & Std. Dev. & Mean & Std. Dev. \\
\hline \multicolumn{9}{|l|}{ Innovation Indicators } \\
\hline AM techniques & 27.03 & 44.44 & 19.44 & 39.63 & 19.89 & 39.95 & 47.74 & 49.98 \\
\hline Organisational structure & 33.63 & 47.28 & 29.55 & 45.68 & 28.62 & 45.24 & 61.61 & 48.66 \\
\hline Marketing & 29.61 & 45.69 & 27.27 & 44.59 & 26.02 & 43.92 & 37.42 & 48.42 \\
\hline Process & 48.17 & 50.00 & 30.51 & 46.10 & 27.55 & 44.72 & 73.44 & 44.19 \\
\hline Product & 47.68 & 49.98 & 41.16 & 49.27 & 42.93 & 49.54 & 74.09 & 43.84 \\
\hline \multicolumn{9}{|l|}{ Innovation Complementarities } \\
\hline Innovation (excl AMT) & 77.72 & 41.64 & 59.32 & 49.18 & 57.78 & 49.43 & & \\
\hline Innovation (excl org. structure) & 75.61 & 42.98 & 56.42 & 49.65 & 55.81 & 49.71 & & \\
\hline Innovation (excl marketing) & 76.32 & 42.54 & 58.11 & 49.40 & 57.42 & 49.49 & & \\
\hline Innovation (excl process) & 72.17 & 44.85 & 56.42 & 49.65 & 57.25 & 49.52 & 90.10 & 29.87 \\
\hline Innovation (excl. product) & 69.95 & 45.88 & 52.30 & 50.01 & 49.02 & 50.04 & 91.07 & 28.58 \\
\hline \multicolumn{9}{|l|}{ Knowledge sourcing } \\
\hline Research and development & 43.17 & 49.57 & 51.82 & 50.03 & 49.91 & 50.04 & 58.81 & 49.24 \\
\hline Other group members & & & 10.41 & 30.58 & 11.45 & 31.87 & 11.94 & 32.44 \\
\hline Backwards linkages & 61.93 & 48.59 & 13.80 & 34.53 & 15.21 & 35.94 & 11.94 & 32.44 \\
\hline Forwards linkages & 43.62 & 49.63 & 13.32 & 34.02 & 15.56 & 36.28 & 9.68 & 29.58 \\
\hline Horizontal linkages & 17.49 & 38.02 & 10.90 & 31.20 & 10.91 & 31.21 & 8.39 & 27.73 \\
\hline Public knowledge sources & 18.73 & 39.05 & 9.69 & 29.61 & 11.99 & 32.51 & 14.62 & 35.35 \\
\hline Georgia Tech & 2.79 & 16.49 & & & & & & \\
\hline \multicolumn{9}{|l|}{ Resource Base } \\
\hline Employment (2002) & 102.43 & 205.54 & 166.76 & 540.71 & 180.11 & 493.13 & & \\
\hline Established post 2000 & 9.88 & 29.86 & 12.22 & 32.79 & 11.72 & 32.20 & & \\
\hline Part of multi-plant group & 43.70 & 49.64 & 40.65 & 49.18 & 40.48 & 49.13 & 40.32 & 49.08 \\
\hline Important group R\&D & & & 62.71 & 48.42 & 58.68 & 49.29 & & \\
\hline \multicolumn{9}{|l|}{ Absorptive Capacity } \\
\hline Science and Eng Grads (\%) & & & 4.71 & 10.18 & 4.59 & 10.95 & & \\
\hline Other Grads $(\%)$ & & & 6.02 & 31.87 & 4.40 & 12.47 & & \\
\hline Training for innovation & 21.31 & 40.98 & 51.01 & 50.05 & 48.05 & 50.01 & 39.14 & 48.83 \\
\hline Investment for innovation & 58.27 & 49.35 & 65.91 & 47.46 & 59.74 & 49.09 & 27.42 & 44.63 \\
\hline \multicolumn{9}{|l|}{ Government Assistance } \\
\hline Local government support & & & 23.23 & 42.28 & 6.69 & 25.01 & 10.22 & 30.30 \\
\hline National government support & & & 20.20 & 40.20 & 9.29 & 29.06 & 20.00 & 40.02 \\
\hline EU support & & & 5.06 & 21.95 & 1.67 & 12.84 & 6.34 & 24.39 \\
\hline \multicolumn{9}{|l|}{ Industry Dummies } \\
\hline Food and textiles & 21.87 & 41.37 & 10.17 & 30.26 & 8.77 & 28.30 & 22.80 & 41.97 \\
\hline Materials based industry & 40.69 & 49.16 & 38.26 & 48.66 & 28.09 & 44.98 & 25.59 & 43.66 \\
\hline Machinery and equipment & 20.02 & 40.04 & 19.85 & 39.94 & 30.77 & 46.20 & 17.20 & 37.76 \\
\hline Electronics and transport & 8.87 & 28.45 & 25.18 & 43.46 & 27.55 & 44.72 & 16.88 & 37.48 \\
\hline
\end{tabular}

Note: Survey responses are weighted to give representative results.

Sources: Georgia Manufacturing Survey (2005); UK Innovation Survey (2005); Spanish Innovation Survey (2000). See text for additional details. 


\section{Table 3: Correlation Matrices}

\begin{tabular}{|c|c|c|c|c|c|c|c|c|c|c|c|}
\hline & $\begin{array}{l}\text { AMT } \\
\text { Techniques }\end{array}$ & $\begin{array}{l}\text { Organisational } \\
\text { structure }\end{array}$ & Marketing & Process & Product & $\begin{array}{l}\text { Research and } \\
\text { Development }\end{array}$ & $\begin{array}{l}\text { Backwards } \\
\text { linkages }\end{array}$ & $\begin{array}{l}\text { Forwards } \\
\text { linkages }\end{array}$ & $\begin{array}{l}\text { Horizontal } \\
\text { linkages }\end{array}$ & $\begin{array}{l}\text { Public } \\
\text { knowledge } \\
\text { sources }\end{array}$ & $\begin{array}{l}\text { Other } \\
\text { group } \\
\text { members } \\
\end{array}$ \\
\hline \multicolumn{12}{|l|}{ A. Wales } \\
\hline \multicolumn{12}{|l|}{ Innovation Indicators } \\
\hline AM techniques & 1.00 & & & & & & & & & & \\
\hline Organisational structure & 0.44 & 1.00 & & & & & & & & & \\
\hline Marketing & 0.33 & 0.37 & 1.00 & & & & & & & & \\
\hline Process & 0.24 & 0.21 & 0.29 & 1.00 & & & & & & & \\
\hline Product & 0.19 & 0.30 & 0.35 & 0.47 & 1.00 & & & & & & \\
\hline \multicolumn{12}{|l|}{ Knowledge sourcing } \\
\hline Research and development & 0.20 & 0.30 & 0.29 & 0.24 & 0.46 & 1.00 & & & & & \\
\hline Backwards linkages & 0.25 & 0.10 & 0.17 & 0.35 & 0.34 & 0.23 & 1.00 & & & & \\
\hline Forwards linkages & 0.30 & 0.17 & 0.20 & 0.32 & 0.33 & 0.27 & 0.81 & 1.00 & & & \\
\hline Horizontal linkages & 0.33 & 0.17 & 0.25 & 0.25 & 0.33 & 0.23 & 0.65 & 0.66 & 1.00 & & \\
\hline Public knowledge sources & 0.28 & 0.17 & 0.15 & 0.22 & 0.23 & 0.26 & 0.63 & 0.67 & 0.51 & 1.00 & \\
\hline Other group members & 0.34 & 0.13 & 0.15 & 0.34 & 0.25 & 0.19 & 0.60 & 0.61 & 0.54 & 0.48 & 1.00 \\
\hline \multicolumn{12}{|l|}{ B. West Midlands } \\
\hline Innovation Indicators & & & & & & & & & & & \\
\hline AM techniques & 1.00 & & & & & & & & & & \\
\hline Organisational structure & 0.48 & 1.00 & & & & & & & & & \\
\hline Marketing & 0.39 & 0.42 & 1.00 & & & & & & & & \\
\hline Process & 0.28 & 0.33 & 0.33 & 1.00 & & & & & & & \\
\hline Product & 0.26 & 0.26 & 0.35 & 0.46 & 1.00 & & & & & & \\
\hline \multicolumn{12}{|l|}{ Knowledge sourcing } \\
\hline Research and development & 0.28 & 0.33 & 0.34 & 0.31 & 0.53 & 1.00 & & & & & \\
\hline Backwards linkages & 0.23 & 0.27 & 0.30 & 0.38 & 0.35 & 0.28 & 1.00 & & & & \\
\hline Forwards linkages & 0.26 & 0.26 & 0.29 & 0.35 & 0.37 & 0.31 & 0.78 & 1.00 & & & \\
\hline Horizontal linkages & 0.22 & 0.25 & 0.28 & 0.25 & 0.25 & 0.22 & 0.71 & 0.70 & 1.00 & & \\
\hline Public knowledge sources & 0.21 & 0.26 & 0.32 & 0.32 & 0.30 & 0.27 & 0.65 & 0.74 & 0.63 & 1.00 & \\
\hline Other group members & 0.22 & 0.28 & 0.25 & 0.29 & 0.27 & 0.26 & 0.71 & 0.70 & 0.63 & 0.52 & 1.00 \\
\hline
\end{tabular}




\begin{tabular}{|c|c|c|c|c|c|c|c|c|c|c|c|}
\hline C. Georgia & $\begin{array}{l}\text { AM } \\
\text { Techniques }\end{array}$ & $\begin{array}{l}\text { Organisational } \\
\text { structure }\end{array}$ & Marketing & Process & Product & $\begin{array}{l}\text { Research and } \\
\text { Development }\end{array}$ & $\begin{array}{l}\text { Backwards } \\
\text { linkages }\end{array}$ & $\begin{array}{l}\text { Forwards } \\
\text { linkages }\end{array}$ & $\begin{array}{l}\text { Horizontal } \\
\text { linkages }\end{array}$ & $\begin{array}{l}\text { Public } \\
\text { knowledge } \\
\text { sources }\end{array}$ & $\begin{array}{l}\text { Georgia } \\
\text { Tech }\end{array}$ \\
\hline \multicolumn{12}{|l|}{ Innovation Indicators } \\
\hline AM techniques & 1.00 & & & & & & & & & & \\
\hline Organisational structure & 0.21 & 1.00 & & & & & & & & & \\
\hline Marketing & 0.18 & 0.16 & 1.00 & & & & & & & & \\
\hline Process & 0.31 & 0.24 & 0.19 & 1.00 & & & & & & & \\
\hline Product & 0.16 & 0.14 & 0.24 & 0.22 & 1.00 & & & & & & \\
\hline \multicolumn{12}{|l|}{ Knowledge sourcing } \\
\hline Research and development & 0.19 & 0.18 & 0.17 & 0.26 & 0.46 & 1.00 & & & & & \\
\hline Backwards linkages & 0.13 & 0.13 & 0.15 & 0.15 & 0.22 & 0.24 & 1.00 & & & & \\
\hline Forwards linkages & 0.16 & 0.23 & 0.18 & 0.21 & 0.29 & 0.34 & 0.36 & 1.00 & & & \\
\hline Horizontal linkages & 0.03 & 0.06 & 0.01 & 0.13 & 0.05 & 0.10 & -0.02 & 0.10 & 1.00 & & \\
\hline Public knowledge sources & 0.09 & 0.08 & 0.08 & 0.19 & 0.11 & 0.15 & 0.06 & 0.15 & 0.27 & 1.00 & \\
\hline Georgia Tech & 0.06 & 0.06 & 0.06 & 0.15 & 0.05 & 0.09 & 0.07 & 0.11 & 0.18 & 0.67 & 1.00 \\
\hline D. Catalonia & $\begin{array}{l}\text { AM } \\
\text { Techniques }\end{array}$ & $\begin{array}{l}\text { Organisational } \\
\text { structure }\end{array}$ & Marketing & Process & Product & $\begin{array}{l}\text { Research and } \\
\text { Development }\end{array}$ & $\begin{array}{l}\text { Backwards } \\
\text { linkages }\end{array}$ & $\begin{array}{l}\text { Forwards } \\
\text { linkages }\end{array}$ & $\begin{array}{l}\text { Horizontal } \\
\text { linkages }\end{array}$ & $\begin{array}{l}\text { Public } \\
\text { knowledge } \\
\text { sources }\end{array}$ & $\begin{array}{l}\text { Other } \\
\text { group } \\
\text { members }\end{array}$ \\
\hline \multicolumn{12}{|l|}{ Innovation Indicators } \\
\hline AM techniques & 1.00 & & & & & & & & & & \\
\hline Organisational structure & 0.42 & 1.00 & & & & & & & & & \\
\hline Marketing & 0.32 & 0.38 & 1.00 & & & & & & & & \\
\hline Process & 0.14 & 0.11 & 0.02 & 1.00 & & & & & & & \\
\hline Product & 0.09 & 0.07 & 0.13 & -0.36 & 1.00 & & & & & & \\
\hline \multicolumn{12}{|l|}{ Knowledge sourcing } \\
\hline Research and development & 0.12 & 0.10 & 0.05 & -0.07 & 0.39 & 1.00 & & & & & \\
\hline Backwards linkages & 0.11 & 0.03 & 0.02 & 0.07 & 0.14 & 0.25 & 1.00 & & & & \\
\hline Forwards linkages & 0.12 & 0.06 & 0.04 & 0.07 & 0.11 & 0.22 & 0.82 & 1.00 & & & \\
\hline Horizontal linkages & 0.08 & 0.02 & 0.01 & 0.07 & 0.10 & 0.22 & 0.80 & 0.86 & 1.00 & & \\
\hline Public knowledge sources & 0.10 & 0.03 & 0.03 & 0.06 & 0.15 & 0.29 & 0.80 & 0.76 & 0.70 & 1.00 & \\
\hline Other group members & 0.11 & 0.07 & 0.06 & 0.11 & 0.13 & 0.24 & 0.77 & 0.82 & 0.79 & 0.73 & 1.00 \\
\hline
\end{tabular}


Table 4: Georgia Model Output

\begin{tabular}{|c|c|c|c|c|c|c|c|c|c|c|}
\hline & \multicolumn{2}{|c|}{ AMT } & \multicolumn{2}{|c|}{ Org. Structure } & \multicolumn{2}{|c|}{ Marketing } & \multicolumn{2}{|c|}{ Process } & \multicolumn{2}{|c|}{ Product } \\
\hline & Coeff & t-stat & Coeff & t-stat & Coeff & t-stat & Coeff & t-stat & Coeff & t-stat \\
\hline $\begin{array}{l}\text { Innovation Complementarities } \\
\text { Innovation (excl AMT) }\end{array}$ & -0.118 & -0.300 & & & & & & & & \\
\hline Innovation (excl org. structure) & & & -0.286 & -0.690 & & & & & & \\
\hline Innovation (excl marketing) & & & & & -0.354 & -0.940 & & & & \\
\hline Innovation (excl process) & & & & & & & -0.464 & -1.100 & & \\
\hline $\begin{array}{l}\text { Innovation (excl. product) } \\
\text { Knowledge sourcing }\end{array}$ & & & & & & & & & -0.579 & -1.310 \\
\hline Research and development & 0.329 & 2.440 & 0.276 & 2.050 & 0.326 & 2.330 & 0.478 & 3.480 & 1.060 & 8.770 \\
\hline Backwards linkages & 0.110 & 0.860 & 0.170 & 1.350 & 0.229 & 1.810 & 0.199 & 1.590 & 0.325 & 2.580 \\
\hline Forwards linkages & 0.240 & 1.820 & 0.420 & 3.310 & 0.290 & 2.340 & 0.204 & 1.580 & 0.385 & 2.900 \\
\hline Horizontal linkages & -0.128 & -0.850 & 0.068 & 0.470 & -0.106 & -0.730 & 0.144 & 1.040 & -0.025 & -0.160 \\
\hline Public knowledge sources & 0.053 & 0.410 & -0.075 & -0.590 & 0.139 & 1.100 & 0.300 & 2.450 & 0.021 & 0.160 \\
\hline Resource Base & & & & & & & & & & \\
\hline Employment (2002) & 0.001 & 1.590 & 0.002 & 1.960 & -0.001 & -1.020 & 0.002 & 2.820 & 0.000 & -0.180 \\
\hline Employment Squared (2002) & 0.000 & -0.030 & -0.008 & -1.210 & 0.004 & 1.910 & -0.006 & -2.210 & 0.003 & 0.720 \\
\hline Established post-2000 & 0.256 & 1.290 & 0.161 & 0.890 & -0.086 & -0.470 & -0.219 & -1.230 & 0.060 & 0.300 \\
\hline Part of multi-plant group & 0.418 & 3.290 & 0.367 & 3.010 & 0.024 & 0.190 & 0.108 & 0.820 & 0.410 & 3.230 \\
\hline Absorptive Capacity & & & & & & & & & & \\
\hline Training for innovation & 0.241 & 1.730 & 0.189 & 1.280 & 0.444 & 3.160 & 0.429 & 3.000 & 0.241 & 1.660 \\
\hline Investment for innovation & 0.305 & 2.310 & 0.227 & 1.860 & 0.175 & 1.410 & 0.527 & 4.550 & 0.179 & 1.320 \\
\hline Industry Dummies & & & & & & & & & & \\
\hline Food and textiles & -0.580 & -2.410 & -0.149 & -0.610 & -0.108 & -0.460 & -0.701 & -2.950 & -0.834 & -3.170 \\
\hline Materials based industry & -0.145 & -0.660 & 0.155 & 0.680 & -0.213 & -1.000 & -0.183 & -0.810 & -0.628 & -2.570 \\
\hline Machinery and equipment & -0.137 & -0.600 & 0.211 & 0.890 & -0.163 & -0.740 & -0.248 & -1.060 & -0.768 & -3.130 \\
\hline Electronics and transport & -0.185 & -0.700 & 0.163 & 0.590 & -0.239 & -0.900 & -0.312 & -1.140 & -0.718 & -2.490 \\
\hline Constant & -1.213 & -3.470 & -1.185 & -3.150 & -0.713 & -2.200 & -0.502 & -1.430 & -0.154 & -0.440 \\
\hline rho21 & 0.23 & 1.71 & & & & & & & & \\
\hline rho31 & 0.28 & 2.55 & 0.29 & 2.24 & & & & & & \\
\hline rho41 & 0.45 & 3.87 & 0.44 & 2.79 & 0.36 & 2.20 & & & & \\
\hline rho51 & 0.17 & 1.00 & 0.21 & 1.05 & 0.44 & 2.76 & 0.40 & 1.70 & & \\
\hline Number of observations & $0+2$ & & & & & & & & & \\
\hline Wald test (Chi2(115) & 408.88 & & & & & & & & & \\
\hline Likelihood ratio & 12516.43 & & & & & & & & & \\
\hline LR test for all coeff 0 chi2(10) & 21489.6 & & & & & & & & & \\
\hline
\end{tabular}


Table 5: Wales Model Output

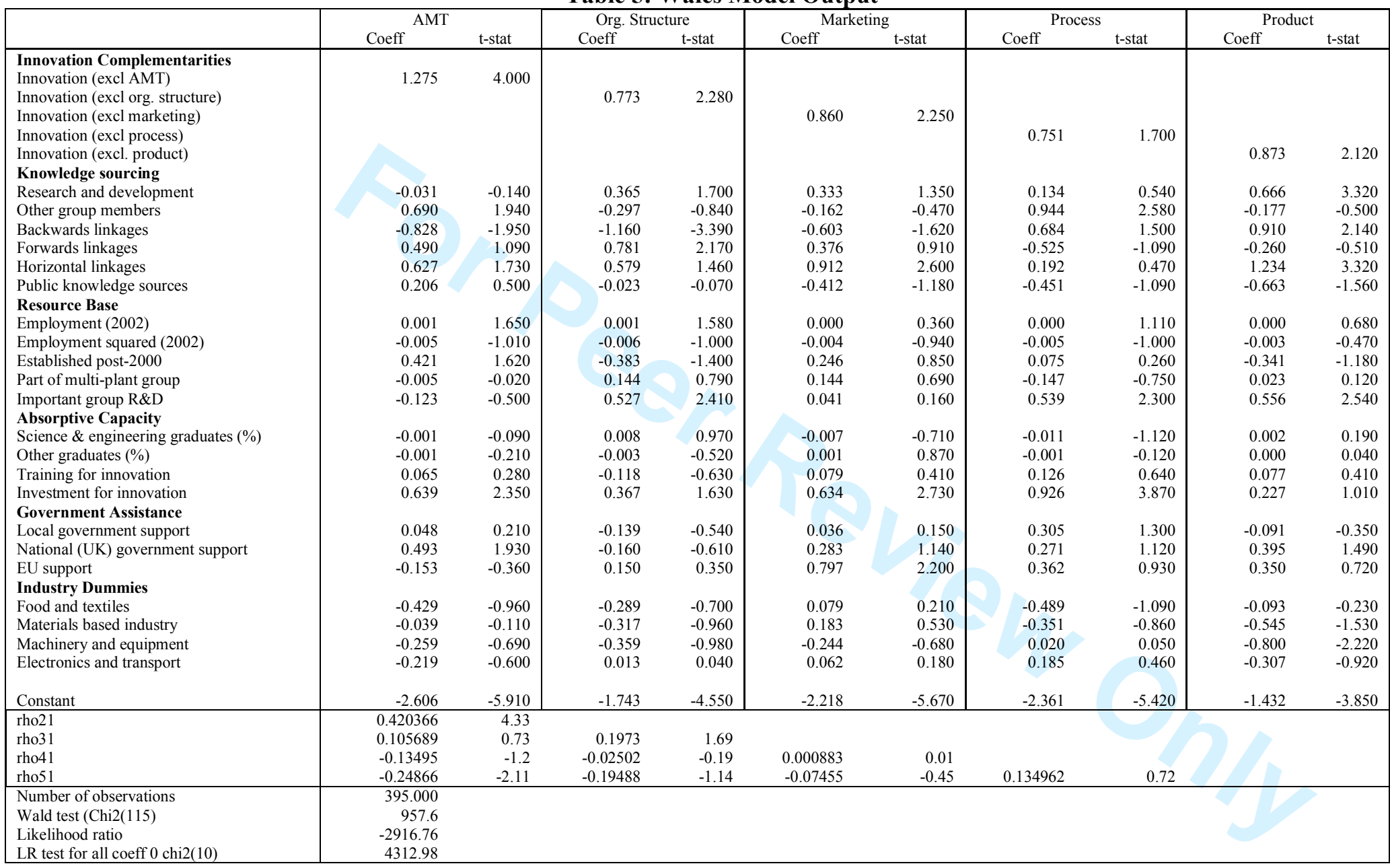


Table 6: West Midlands Model Output

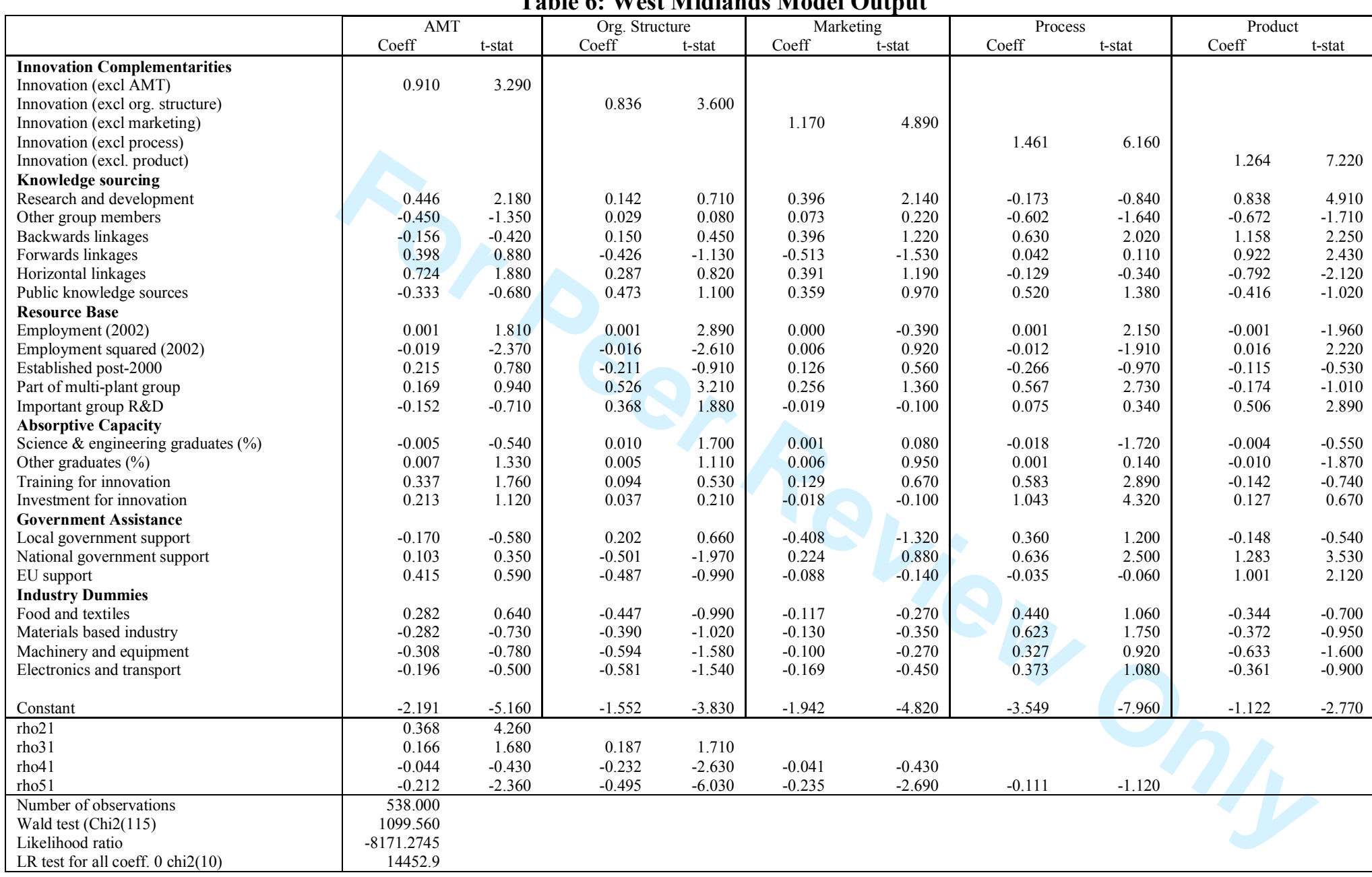


Table 7: Catalonia Model Output

\begin{tabular}{|c|c|c|c|c|c|c|c|c|c|c|}
\hline & \multicolumn{2}{|c|}{ AMT } & \multicolumn{2}{|c|}{ Org. Structure } & \multicolumn{2}{|c|}{ Marketing } & \multicolumn{2}{|c|}{ Process } & \multicolumn{2}{|c|}{ Product } \\
\hline & Coeff & t-stat & Coeff & t-stat & Coeff & t-stat & Coeff & t-stat & Coeff & t-stat \\
\hline $\begin{array}{l}\text { Innovation Complementarities } \\
\text { Innovation (excl process) }\end{array}$ & & & & & & & -4.484 & -0.05 & & \\
\hline Innovation (excl. product) & & & & & & & & 0.00 & -2.570 & -1.52 \\
\hline Knowledge sourcing & 0.074 & 0.78 & 0.208 & 2.23 & 0.023 & 0.24 & -0.230 & -2.2 & 0.998 & 8.93 \\
\hline Research and development & -0.115 & -0.45 & 0.476 & 1.79 & 0.417 & 1.67 & 0.914 & 2.86 & 0.110 & 0.3 \\
\hline Backwards linkages & -0.039 & -0.14 & -0.225 & -0.78 & -0.321 & -1.13 & -0.135 & -0.46 & 0.714 & 1.54 \\
\hline Forwards linkages & 0.984 & 2.67 & 0.837 & 2.14 & 0.439 & 1.25 & -0.250 & -0.61 & -0.166 & -0.3 \\
\hline Horizontal linkages & -0.577 & -1.61 & -0.759 & -2 & -0.314 & -0.99 & -0.007 & -0.02 & -0.696 & -1.21 \\
\hline Public knowledge sources & -0.172 & -0.79 & -0.324 & -1.49 & -0.304 & -1.38 & -0.119 & -0.52 & 0.116 & 0.36 \\
\hline Resource Base & & & & & & & & & & \\
\hline Part of multi-plant group & 0.294 & 3.18 & 0.026 & 0.29 & -0.014 & -0.15 & -0.010 & -0.1 & 0.221 & 1.97 \\
\hline Absorptive Capacity & & & & & & & & & & \\
\hline Training for innovation & 0.435 & 4.59 & 0.167 & 1.77 & -0.026 & -0.27 & 0.527 & 4.99 & -0.135 & -1.17 \\
\hline Investment for innovation & 0.186 & 1.81 & 0.066 & 0.65 & 0.633 & 6.27 & 0.029 & 0.26 & 0.829 & 5.92 \\
\hline Government Assistance & & & & & & & & & & \\
\hline Local government support & 0.225 & 1.87 & 0.072 & 0.6 & 0.195 & 1.64 & 0.089 & 0.67 & -0.036 & -0.23 \\
\hline National government support & 0.222 & 1.55 & -0.044 & -0.31 & 0.011 & 0.08 & 0.312 & 1.84 & 0.144 & 0.8 \\
\hline EU support & 0.001 & 0.01 & 0.100 & 0.5 & 0.007 & 0.03 & 0.350 & 1.5 & 0.148 & 0.54 \\
\hline Industry Dummies & & & & & & & & & & \\
\hline Food and textiles & -0.040 & -0.29 & 0.048 & 0.34 & -0.115 & -0.83 & 0.204 & 1.37 & 0.052 & 0.3 \\
\hline Materials based industry & -0.019 & -0.14 & 0.170 & 1.25 & -0.095 & -0.69 & 0.302 & 2.03 & -0.047 & -0.28 \\
\hline Machinery and equipment & -0.262 & -1.74 & 0.072 & 0.49 & -0.133 & -0.9 & 0.292 & 1.81 & -0.154 & -0.84 \\
\hline Electronics and transport & -0.080 & -0.54 & 0.188 & 1.28 & -0.270 & -1.82 & 0.021 & 0.13 & 0.101 & 0.53 \\
\hline Constant & -0.438 & -3.28 & -0.037 & -0.29 & -0.418 & -3.14 & 4.699 & 0.05 & 2.419 & 1.43 \\
\hline rho21 & 0.566 & 14.51 & & & & & & & & \\
\hline rho31 & 0.435 & 9.65 & 0.591 & 15.54 & & & & & & \\
\hline rho41 & 0.134 & 2.18 & 0.204 & 3.32 & 0.206 & 3.39 & & & & \\
\hline rho51 & 0.289 & 5.47 & 0.223 & 4.04 & 0.132 & 2.34 & -0.387 & -4.64 & & \\
\hline Number of observations & 930 & & & & & & & & & \\
\hline Wald test (Chi2(115) & 346.69 & & & & & & & & & \\
\hline Likelihood ratio & -2467.946 & & & & & & & & & \\
\hline LR test for all coeff 0 chi2 $(10)$ & 403.019 & & & & & & & & & \\
\hline
\end{tabular}


Table 8: Symbolic Summary

\begin{tabular}{|c|c|c|c|c|c|c|c|c|c|c|c|c|c|c|c|c|c|c|c|c|}
\hline & \multicolumn{5}{|c|}{ Georgia } & \multicolumn{5}{|c|}{ Wales } & \multicolumn{5}{|c|}{ West Midlands } & \multicolumn{5}{|c|}{ Catalonia } \\
\hline & AMT & $\mathrm{OS}$ & MKT & PROC & PROD & AMT & $\mathrm{OS}$ & MKT & PROC & PROD & AMT & $\mathrm{OS}$ & MKT & PROC & PROD & AMT & OS & MKT & PROC & PROD \\
\hline Innovation Complementarities & & & & & & & & & & & & & & & & & & & & \\
\hline $\begin{array}{l}\text { Innovation (excl AMT) } \\
\text { Innovation (excl org. structure) }\end{array}$ & $(-)$ & $(-)$ & & & & + & + & & & & + & + & & & & & & & & \\
\hline Innovation (excl marketing) & & & $(-)$ & & & & & + & & & & & + & & & & & & & \\
\hline $\begin{array}{l}\text { Innovation (excl process) } \\
\text { Innovation (excl nodyct) }\end{array}$ & & & & $(-)$ & & & & & $(+)$ & & & & & + & & & & & $(-)$ & \\
\hline $\begin{array}{l}\text { Innovation (excl. product) } \\
\text { Knowledge sourcing }\end{array}$ & & & & & $(-)$ & & & & & + & & & & & + & & & & & $(-)$ \\
\hline Research and development & + & + & + & + & + & $(-)$ & $(+)$ & $(+)$ & $(+)$ & + & + & $(+)$ & + & $(-)$ & + & $(+)$ & + & $(+)$ & - & + \\
\hline Other group members & & & & & & $(+)$ & $(-)$ & $(-)$ & + & $(-)$ & $(-)$ & $(+)$ & $(+)$ & $(-)$ & $(-)$ & $(-)$ & + & $(+)$ & + & $(+)$ \\
\hline Backwards linkages & $(+)$ & $(+)$ & $(+)$ & $(+)$ & + & $(-)$ & - & $(-)$ & $(+)$ & + & $(-)$ & $(+)$ & $(+)$ & + & + & $(-)$ & $(-)$ & $(-)$ & $(-)$ & $(+)$ \\
\hline Forwards linkages & $(+)$ & + & + & $(+)$ & + & $(+)$ & + & $(+)$ & $(-)$ & $(-)$ & $(+)$ & $(-)$ & $(-)$ & $(+)$ & + & + & + & $(+)$ & $(-)$ & $(-)$ \\
\hline Horizontal linkages & $(-)$ & $(+)$ & $(-)$ & $(+)$ & $(-)$ & $(+)$ & $(+)$ & + & $(+)$ & + & $(+)$ & $(+)$ & $(+)$ & $(-)$ & - & $(-)$ & - & $(-)$ & $(-)$ & $(-)$ \\
\hline Public knowledge sources & $(+)$ & $(-)$ & $(+)$ & + & $(+)$ & $(+)$ & $(-)$ & $(-)$ & $(-)$ & $(-)$ & $(-)$ & $(+)$ & $(+)$ & $(+)$ & $(-)$ & $(-)$ & $(-)$ & $(-)$ & $(-)$ & $(+)$ \\
\hline Resource Base & & + & $(-)$ & & & & & & & & & & & & & & & & & \\
\hline $\begin{array}{l}\text { Employment (2002) } \\
\text { Employment Squared (2002) }\end{array}$ & $\begin{array}{c}(+) \\
(-)\end{array}$ & ${ }_{(-)}^{+}$ & $\begin{array}{l}(-) \\
(+)\end{array}$ & + & $\begin{array}{l}(-) \\
(+)\end{array}$ & $(+)$ & $(+)$ & 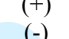 & $(+)$ & $(+)$ & $(+)$ & + & $\begin{array}{l}(-) \\
(+)\end{array}$ & + & $(-)$ & & & & & \\
\hline $\begin{array}{l}\text { Employment Squared (2002) } \\
\text { Established post } 2000\end{array}$ & $(+)$ & $\begin{array}{l}(+) \\
(-) \\
(+)\end{array}$ & $\begin{array}{c}(+) \\
(-)\end{array}$ & $(-\bar{r})$ & $\begin{array}{l}(+) \\
(+)\end{array}$ & $\begin{array}{l}(-) \\
(+)\end{array}$ & $\begin{array}{l}(-) \\
(-)\end{array}$ & $\begin{array}{l}(-) \\
(+)\end{array}$ & $\begin{array}{l}(-) \\
(+)\end{array}$ & $\begin{array}{l}(-) \\
(-)\end{array}$ & $\begin{array}{c}- \\
(+)\end{array}$ & (-) & $(++)$ & $(-)$ & + & & & & & \\
\hline & + & (7) & $\begin{array}{ll}(-1) \\
(+)\end{array}$ & $(+)$ & & $(-)$ & & & $(-)$ & $(-)$ & $(+)$ & $(-)$ & $(+)$ & $(-)$ & $(-)$ & & & & & \\
\hline Part of multi-plant group & + & & (+) & $\left(^{+}\right)$ & + & $(-)$ & (+) $^{(2)}$ & (+) & $(-)$ & $(+)$ & $(+)$ & + & $(+)$ & + & $(-)$ & + & $(+)$ & $(-)$ & $(-)$ & + \\
\hline $\begin{array}{l}\text { Important group R\&D } \\
\text { Absorptive Capacity }\end{array}$ & & & & & & $(-)$ & + & $(+)$ & + & & $(-)$ & $(+)$ & $(-)$ & $(+)$ & + & & & & & \\
\hline $\mathrm{g}$ grads $(\%)$ & & & & & & $(-)$ & $(+)$ & $(-)$ & $(-)$ & $(+)$ & $(-)$ & $(+)$ & $(+)$ & $(-)$ & $(-)$ & & & & & \\
\hline Other graduates $(\%$ & & & & & & $(-)$ & $(-)$ & $(+)$ & $(-)$ & $(+)$ & $(+)$ & $(+)$ & $(+)$ & $(+)$ & $(-)$ & & & & & \\
\hline Training for il & $(+)$ & $(+)$ & + & + & $(+)$ & $(+)$ & $(-)$ & $(+)$ & $(+)$ & $(+)$ & $(+)$ & $(+)$ & $(+)$ & + & $(-)$ & + & + & $(-)$ & + & $(-)$ \\
\hline Investment for innovation & + & $(+)$ & $(+)$ & + & $(+)$ & + & $(+)$ & + & + & $(+)$ & $(+)$ & $(+)$ & $(-)$ & + & $(+)$ & + & $(+)$ & + & $(+)$ & + \\
\hline Govern & & & & & & & & & & & & & & & & & & & & \\
\hline Local g & & & & & & $(+)$ & $(-)$ & $(+)$ & $(+)$ & $(-)$ & $(-)$ & $(+)$ & $(-)$ & $(+)$ & $(-)$ & $(+)$ & $(-)$ & $(+)$ & + & $(+)$ \\
\hline Nation & & & & & & $(+)$ & $(-)$ & $(+)$ & $(+)$ & $(+)$ & $(+)$ & - & $(+)$ & + & + & + & + & $(+)$ & $(+)$ & $(-)$ \\
\hline $\begin{array}{l}\text { EU support } \\
\text { Industry Dun }\end{array}$ & & & & & & $(-)$ & $(+)$ & + & $(+)$ & $(+)$ & $(+)$ & $(-)$ & $(-)$ & $(-)$ & + & $(-)$ & $(+)$ & $(+)$ & $(+)$ & $(+)$ \\
\hline $\begin{array}{l}\text { Industry Dummies } \\
\text { Food and textiles }\end{array}$ & - & $(-)$ & $(-)$ & - & - & $(-)$ & $(-)$ & $(+)$ & $(-)$ & $(-)$ & $(+)$ & $(-)$ & $(-)$ & $(+)$ & $(-)$ & $(-)$ & $(+)$ & $(-)$ & + & $(+)$ \\
\hline & $(-)$ & $(+)$ & $(-)$ & $(-)$ & - & $(-)$ & $(-)$ & $(+)$ & $(-)$ & $(-)$ & $(-)$ & $(-)$ & $(-)$ & $(+)$ & $(-)$ & $(-)$ & $(+)$ & $(-)$ & + & $(-)$ \\
\hline Machinery and equipment & $(-)$ & $(+)$ & $(-)$ & $(-)$ & - & $(-)$ & $(-)$ & $(-)$ & $(+)$ & - & $(-)$ & $(-)$ & $(-)$ & $(+)$ & $(-)$ & - & $(+)$ & $(-)$ & $(+)$ & $(-)$ \\
\hline Electronics and transport & $(-)$ & $(+)$ & $(-)$ & $(-)$ & - & $(-)$ & $(+)$ & $(+)$ & $(+)$ & $(-)$ & $(-)$ & $(-)$ & $(-)$ & $(+)$ & $(-)$ & $(-)$ & $(+)$ & - & $(+)$ & $(+)$ \\
\hline Constant & & & & $(-)$ & $(-)$ & t & - & - & - & - & & - & - & & - & - & $(-)$ & - & $(+)$ & $(+)$ \\
\hline
\end{tabular}

Note: Direction of relationship from regional model output is indicated. Symbols not in parentheses are significant at $5 \%$ confidence level 
Figure 1: Study Regions Classified by External Connectivity and Internal Innovation Synergies

\begin{tabular}{|c|c|l|l|}
\cline { 3 - 4 } \multicolumn{2}{|c|}{} & \multicolumn{2}{c|}{ External Connectivity } \\
\cline { 3 - 4 } & Low & High \\
\hline $\begin{array}{c}\text { Internal } \\
\text { Innovation } \\
\text { Synergies }\end{array}$ & Low & Catalonia & Georgia \\
\cline { 3 - 4 } & High & Wales & \\
& & West Midlands & \\
\hline
\end{tabular}




\section{NOTES}

1. In earlier studies we have considered the role of external factors in shaping comparative levels of innovation in Ireland and Israel (e.g. ROPER and FRENKEL, 2000), the UK and Germany (LOVE and ROPER, 2004) and Malaysia (SHAPIRA et al., 2006).

2. For example, the definition of product innovation as used in the UK CIS4 is: 'a product innovation is the market introduction of a new good or service or a significantly improved good or service with respect to its capabilities, such as quality, user friendliness, software or subsystems'. The definition of process innovation is: 'process innovation is the use of new or significantly improved methods for the production or supply of goods and services. The innovation must be new to your enterprise, but it does not need to be new to your industry'. The Spanish CIS definition of product and process innovation is comparable. Similar definitions are found in the 2005 Georgia Manufacturing Survey, where 'A product innovation is the introduction of a new of significantly improved good or service. The innovation must be new to your facility but does not need to be new to your sector or market.' The definition further excludes resale of goods purchased elsewhere or changes to colour or look. In the Georgia survey, 'A process innovation is the implementation of a new or significantly improved production process or method of providing services. The innovation must be new to your facility but does not need to be new to your sector or market'.

3. The definition of wider innovation in the UK CIS4 is: 'new or significantly amended forms of organisation, business structures or practices, aimed at step changes in internal efficiency of effectiveness or in approaching markets and 
customers.' The Georgia survey asks about wider innovation changes through probing organizational innovation ('new or significant changes in firm structure, management methods, or information exchange systems') and marketing innovation ('new or significant changes in your marketing methods to increase the appeal of your goods or services or enter new markets').

4. UK CIS4 Questionnaire, question 13.

5. FALK (2006) argues that these error covariances also give an indication of the links between innovation types. On this basis, we would interpret universally positive complementarities in Georgia but find a more mixed pattern in the two UK study regions.

6. Running the US and UK models restricting the sample to product and process innovators provides an indication of the likely effect of different sampling rules. In general the results are very similar to those presented here in terms of the determinants of innovation of each type. In terms of complementarities between types of innovation the results for the Georgian sample of product and process innovators are also similar to those presented here. In the UK, however, a different pattern of complementarities emerges suggesting that this element of our comparative analysis is most sensitive in the UK case.

7. We find similar results when we run the model without including proxies for complementarity. In this case, the correlation error between product and process innovation is also negative and significant.

8. There is also the potential for some simultaneity between these variables and firms' involvement in innovation itself. As the models suggest, however, any such effect is far from uniform across different sorts of innovative activity and the different study regions. 
9. Some care is necessary in interpreting this policy impact given the welldocumented lack of consistency of such policy treatment effects (see MADDALA, 1973; WoOLDRIDGE, 2002). 


\section{REFERENCES}

Arora, A. and Gambardella, A. (1990) Complementarity and external linkages: the strategies of the large firms in biotechnology, Journal of Industrial Economics, 38, 361-79.

Athey, S. and Schmutzler, A. (1995) Product and pro flexibility in an innovative environment, RAND Journal of Economics, 26, 557-574.

BACARIA, J., Borras, S. and FERnAndEZ-RIBAS, A. (2004) The changing institutional structure and performance of the Catalan innovation system, in COOKE $\mathrm{P}$, HeIDEnREICH, M. and BRACZYK, H. (Eds.) Regional Innovation Systems. The Role of Governances in a Globalized World, pp. 63-90. Routledge, London.

BAKER, A. and GILL, J. (2005) Rethinking innovation in pharmaceutical R\&D, Journal of Commercial Biotechnology, 12, 1, 45-49.

Brand, S., HiLl, S. and Munday, M. (2000) Assessing the impacts of foreign manufacturing on regional economies: the cases of Wales, Scotland and the West Midlands, Regional Studies, 34, 4, 343-355.

BRouwer E. and KLEINKNECHT A. (1996) Determinants of innovation: a microeconometric analysis of three alternative innovation output indicators, in KleINKNeCHT, A. (Ed.), Determinants of Innovation: the Message from New Indicators. Macmillan Press. London and Basingstoke.

BUREAU OF ECONOMIC ANALYSIS (2007) Gross-Domestic-Product-by-Industry Accounts, 1947-2005. US Department of Commerce, Washington, DC. Available at: http://www.bea.gov/bea/industry/gpotables/ (Accessed March 19, 2007). 
CAMBRIDGE-MIT INSTITUTE (2006) UK plc: Just how innovative are we? Findings from the Cambridge-MIT International Innovation Benchmarking Project. Available at: http://www.cbr.cam.ac.uk/pdf/InnovationBenchmarking1-7.pdf

Cassiman, B. and Veugelers, R. (2002) Complementarity in the innovation strategy: internal R\&D, external technology acquisition, and co-operation in R\&D, EARIE Annual Conference, Madrid, September.

CoE, N. M. and Blundell, T. G. (2003) Spatialising knowledge communities: towards a conceptualisation of trans-national innovation networks, Global Networks, 3, 4, 437-456.

Cohen W. M. and Levinthal D. A. (1989) Innovation and learning: the two faces of R\&D, Economic Journal, 99, 569-596.

Cohen W. M. and Levinthal D. A. (1990) Absorptive capacity: a new perspective on learning and innovation, Administrative Science Quarterly, EARIE, 128152.

Cooke, P. (2004) The regional innovation system in Wales, in Regional Innovation Systems. The Role of Governances in a Globalized World. Routledge, London.

Cooke, P. and Morgan, K. (1999) The Associational Economy: Firms, Regions and Innovation. Oxford University Press, Oxford.

CoOke, P., Morgan, K. and Price, A. (1995) Regulating regional economies: Wales and Baden-Wurttemberg in transition, in RHODES, M (Ed.) The Regions and the New Europe: Patterns in Core and Periphery Development, pp. 106-135. Manchester University Press, Manchester.

Dawson, J., ShiPton, H. and West, M. (2005) How can HRM promote organisational innovation, People Management, 11, 8, 52. 
EUROPEAN COMMUNITIES (2004) Innovation in Europe: Results for the EU, Iceland and Norway. Office for Official Publications of the European Communities, Luxembourg.

FALK, M. (2006) Characteristics of technological and organisational innovations. Working Paper, April. Austrian Institute of Economic Research, Vienna.

FERnANDEZ-RiBAs, A. (2003) El model d'innovació català, Documents de Reflexió Estratègica, Departament de la Presidència, Generalitat de Catalunya, 6, 1.

FERNANDEZ-RIBAS, A. and SHAPIRA, P. (2007), The impact of national innovation programs on the conduct of international cooperation in innovation, International Journal of Technology Management, forthcoming.

FREel M.S. (2005) Patterns of innovation and skills in small firms, Technovation, 25, $2,123-134$.

FulLer, C. and PhelPs, N. A. (2004) Multinational enterprises, repeat investment and the role of aftercare services in Wales and Ireland, Regional Studies, 38, 7, $783-801$.

GEROSKI, P. A. (1990) Innovation, technological opportunity, and market structure, Oxford Economic Papers, 42, 586-602.

HARRIS R. I. D. and TRAINOR M. (1995) Innovations and R\&D in Northern Ireland manufacturing: a Schumpeterian approach, Regional Studies, 29, 593-604.

Hayes, R., WheElwright, S.C. and Clark, K. (1988) Dynamic Manufacturing Creating the Learning Organisation. Free Press, New York, NY.

Hewitt-Dundas, H., Andréosso-O'Callaghan, B., Crone, M. and Roper, S. (2005) Knowledge transfers from multi-national plants in Ireland - a crossborder comparison of supply chain linkages, European Urban and Regional Studies, 12, 1, 23-43. 
Kim, J., SANGJOOn, J. L. and MARschKe, G. (2004) Relation of firm size to R\&D productivity, Working Paper. Department of Economics, State University of New York, Albany, NY. Available at: http://www.albany.edu/econ/Research/2004/rdprod.pdf.

LAMBERT, R. (2003) Lambert Review of Business-University Collaboration. Final Report, HM Treasury, London. Available at: http://www.hmtreasury.gov.uk/media/EA556/lambert_review_final_450.pdf.

LEVIEN R. and REISS P. (1984) Tests of a Schumpeterian model of R\&D and market structure, in GrILLICHES Z. (Ed) R\&D, Patents and Productivity. University of Chicago Press, Chicago.

LightFoot, D. (2006) Building the Science of Science Policy: Innovation, Investments and Outcomes. National Science Foundation, Arlington, Virginia.

LöÖF, H. and Heshmati, A. (2001) On the Relationship between Innovation and Performance: A Sensitivity Analysis. SSE/EFI Working Paper No 446. Stockholm School of Economics, Stockholm.

LÖÖF, H. and HeShMATI, A. (2002), Knowledge capital and performance heterogeneity: a firm level innovation study, International Journal of Production Economics, 76, 61-85.

LOVE, J. H. and RoPeR, S. (1999) R\&D, technology transfer and networking effects on innovation intensity, Review of Industrial Organisation, 15, 43-64.

LOVE, J. H. and ROPER, S. (2001) Location and network effects on innovation success: evidence for UK, German and Irish manufacturing plants, Research Policy, 30, 643-61. 
LOVE, J. H. and ROPER, S. (2004) The organisation of innovation: collaboration, cooperation and multifunctional groups in UK and German Manufacturing, Cambridge Journal of Economics, 28, 379-395.

Love, J., Driffield, N., Roper, S, and SCOTT, J. (1996) Factors Influencing the Relative Economic Performance of the West Midlands - Summary Report. West Midlands Regional Observatory, Birmingham. Available at: http://www.wmro.org.

MadDALA, G. (1993) Limited Dependent and Qualitative Variables in Econometrics. Cambridge University Press, New York.

MARburger, J. (2005) Wanted: Better Benchmarks (Editorial). Science, 308.

MERIT (2006) European Innovation Scoreboard 2006. Maastricht Economic Research Institute on Innovation and Technology, Maastricht, Belgium.

Michie, J. AND SheeHAN, M. (2003) Labour market deregulation, 'flexibility' and innovation, Cambridge Journal of Economics, 27, 1, 123-143.

MiLgrom, P. and RoBerTs, J. (1990) The economics of modern manufacturing: technology, strategy, and organization, American Economic Review, 80, 511528.

Milgrom, P. and RoBerTs, J. (1995) Complementarities and fit: strategy, structure, and organizational change in manufacturing, Journal of Accounting and Economics, 19, 179-208.

Miravete, E. and Permias, J. C. (2004) Innovation Complementarity and the Scale of Production. CEPR Discussion Paper 2004/07. Centre for Economic Policy Research, London.

Mohapatra, S., Cheney, D., Shapira, P., Youtie, J., Lamos, E., and Bhaskarabhatla, A. (2006) Product and Service Innovation. Report 
prepared for the National Institute of Standards and Technology, US Department of Commerce, SB 1341-03-Z-0014. SRI International, Arlington, VA, and the Georgia Tech Program in Science, Technology and Innovation Policy, Atlanta, GA.

MorgAN, B. (2002) Higher education and regional economic development in Wales: an opportunity for demonstrating the efficacy of devolution in economic development, Regional Studies, 36, 1, 65-73.

Morgan, K., BrooksBAnK, D. and CONNOLLy, M. (2000) The role of networking in the new political economy of regional development, European Planning Studies, 8, 3, 319-336.

NAtional Science Foundation (2005) Research and Development in Industry: 2001. NSF 05-305, Division of Science Resources Statistics. Arlington, VA.

NAtional ScIENCE Foundation (2006) Science and Engineering State Profiles: 2003-04. NSF 06-314. Arlington, VA. Available at http://www.nsf.gov/statistics/nsf06314/ (accessed March 19, 2007).

O’Shea, R., Allen, T. J. and Chevalier, A. and Roche, F. (2005) Entrepreneurial orientation, technology transfer and spin-off performance of U.S. universities, Research Policy, 34, 7, 994-1009.

OECD (2005) The Oslo Manual: Guidelines for Collecting and Interpreting Innovation Data, 3rd Edition. Organisation for Economic Cooperation and Development, Paris.

Oerlemans, L. A. G., Meeus, M. T. H. and Boekema, F. W. M. (2001) On the spatial embeddedness of innovation networks: an exploration of the proximity effect, Tijdschrift Voor Economische En Sociale Geografie, 92, 1, 60-75. 
OINAS, P. (1999) Activity-specificity in organisational learning: implications for analysing the role of proximity, Geojournal, 49, 363-72.

PORTER, M E (1980) Competitive strategy : techniques for analyzing industries and competitor, Free Press, New York.

Pittaway, L., Robertson, M., Munir, K., Denyer, D. and Neely, A. (2004) Networking and innovation: a systematic review of the evidence, International Journal of Management Reviews, 5-6, 3-4.

QuAH, D. (2001) The weightless economy in economic development, in POHJOLA, M. (Ed.) Information Technology, Productivity and Economic Growth: International Evidence and Implications for Economic Development. Oxford University Press, Oxford.

Robson, S. and ORTMAns, L. (2006) First findings from the UK innovation survey 2005, Economic Trends, 628, March.

Roper, S. and FrenKel, A. (2000) Different paths to success? The electronics industry in Israel and Ireland, Environment and Planning C, 18, 651-665.

ROPER, S. and HEWITT-DUNDAS, N. (2005) Measuring the impact of grant support for innovation: panel data evidence for Irish firms. European Regional Science Association, Amsterdam, August.

ROPER, S. and HEWITT-DUNDAS, N. (2006) International Innovation Comparisons: Insight or Illusion?, Environment and Planning C, 24, 3, 385-401.

ROPER, S., Du, J., and Love, J. H. (2006) Knowledge Sourcing and Innovation, Working Paper, Aston Business School (RP0605).

SalazAr, M. and HolbrooK, A. (2004) A debate on innovation surveys. Science and Public Policy, 31, 4, 254-266.

SAmuelson, P. A. (1974) Complementarity, an essay on the 40th anniversary of the Hicks-Allen revolution in demand theory, Journal of Economic Literature, 12, 4, 1255-1289. 
SCHMiDT, T. and RAMmER, C. (2006) The Determinants and Effects of Technological and Non-technological Innovations - Evidence from the German CIS IV. ZEW, Mannheim, Germany.

SHAPIRA. P. (2005) Innovation challenges and strategies in catch-up regions: developmental growth and disparities in Georgia, USA, in FUCHS, G. and SHAPIRA, P. (Eds.) Rethinking Regional Innovation and Change: Path Dependency or Regional Breakthrough? pp. 195-221. Springer, New York.

Shapira, P., Youtie, J., Yogeesvaran, K., and JaAfar, Z. (2006) Knowledge economy measurement: methods, results and insights from the Malaysian knowledge content study, Research Policy, 35, 10, 1522-1537.

SHERGILL, G. S. and NARGUDKAR, R. (2005) Market orientation, marketing innovation as performance drivers: extending the paradigm, Journal of Global Marketing, 19, 1, 27-47.

TEATHER, B. (2001) Identifying Innovation, Innovators and Innovative Behaviours: A Critical Assessment of the Community Innovation Surveys (CIS). CRIC Discussion Paper No. 48. Centre for Research on Innovation and Competition, University of Manchester, Manchester, UK, December.

WoOLDRIDGE, J. (2002) Econometric analysis of cross section and panel data. MIT Press, Cambridge, MA.

YoUTIE, J. and SHAPIRA, P. (2007) Innovation strategies and manufacturing practices: insights from the 2005 Georgia manufacturing survey, in SuSMAN, G.I., Small and Medium Sized Enterprises in the Global Economy, pp. 46-58. Edward Elgar, Northampton MA and Cheltenham, UK.

Youtie, J., ShaPira, P., Slanina, J., WAng, J., and Zhang, J. (2005). Innovation in Manufacturing: Needs, Practices, and Performance in Georgia, 2002-2005. 
GaMEP Evaluation Working Paper E200502. Georgia Tech Policy Project on Industrial Modernization, Georgia Institute of Technology, Atlanta, GA.

ZAHRA S. A. and GeORGE G. (2002) Absorptive capacity: a review, reconceptualization, and extension, Academy of Management Review, 27, 185203.

ZENGER, T. (2002) Crafting internal hybrids: complementarities, common change initiatives, and the team-based organization, International Journal of the Economics of Business, 9, 79-95. 